Piotr Krasny

Instytut Historii Sztuki, Uniwersytet Jagielloński

http://dx.doi.org/10.18778/2084-851X.05.02

\title{
Altare contra altare. Dysputa o kształcie ołtarza i o jego wystroju w epoce nowożytnej
}

edna świątynia nie może być wznoszona przeciwko drugiej, ani jeden ołtarz przeciwko drugiemu, ponieważ mamy jedną świątynię, jedną arkę, jeden ołtarz [...] tak jak mamy jednego Chrystusa, w którym objawił się Bóg i w którym Go odnajdujemy 9 - głosił Marcin Luter (1483-1546) w komentarzu do Psalmu 132, opublikowanym w roku $1530^{1}$. Słowa te nie przystawały jednak do rzeczywistości, którą reformator ów w znacznym stopniu wykreował. Podzieleni w wierze uczniowie Chrystusa, w wśród nich także sam Luter, obmyślali bowiem w owym czasie różne koncepcje świątyń i ołtarzy, zamierzając stawiać je właśnie jedne przeciwko drugim. Za pomocą programów ideowych i form owych struktur próbowano bardzo często bronić elementów doktryny swojej konfesji, odrzucanych przez inne wyznania, a nieraz także - postponować doktrynę oponentów². Nowożytna teoria sztuki sakralnej - tak jak nowożytna teologia - była formułowana 
w atmosferze kontrowersji, toteż w jej opisie trudno poprzestać na prezentacji jednego stanowiska, ale należy raczej prezentować ją jako zderzenia różnych koncepcji ${ }^{3}$.

Taka metoda badawcza jest - jak sądzę - najwłaściwsza dla studiów nad refleksją o ołtarzu chrześcijańskim, rozwijaną w XVI i XVII wieku. Mogłoby się co prawda wydawać, że na obszarach, na których - tak jak w Polsce - zachowały się niemal wyłącznie ołtarze służące tylko jednej konfesji, można by poprzestać na zgłębianiu teorii, formowanej na użytek tego wyznania. Trzeba jednak pamiętać, że niemal wszystkie europejskie państwa były w początkach epoki nowożytnej podzielone wyznaniowo. Każda z konfesji musiała konfrontować nieustannie swoją koncepcję kształtowania ołtarza z rozwiązaniami innych denominacji. Mogło to prowadzić zarówno do silniejszego akcentowania swych specyficznych rozwiązań, jak i do przejmowania niektórych pomysłów oponentów ${ }^{4}$. Poszukiwanie śladów owych działań może więc doprowadzić do znacznego wzbogacenia badań historyczno-artystycznych nad nowożytnymi ołtarzami, pozwalając zrozumieć lepiej ich programy treściowe i formy artystyczne. Niniejszy szkic chciałbym uczynić pomocą dla podejmujących takie studia. Zarysowuję w nim zasadnicze problemy, wokół których obracała się - jak sądzę - nowożytna dysputa o ołtarzu, udokumentowana przede wszystkim w tekstach teologicznych i powiązanych ze sprawowaniem liturgii, a także dostrzeżona przez autorów rozpraw teoretyczno-artystycznych.

\section{Symbolika ołtarza chrześcijańskiego}

Bardzo bogata symbolika ołtarza chrześcijańskiego, wypracowana na podstawie Starego i Nowego Testamentu przez Ojców Kościoła oraz średniowiecznych teologów, mistyków i poetów religijnych ${ }^{5}$, była de facto niemożliwa do ogarnięcia, bez pomocy dzieł, w których dokonano jej integracji ${ }^{6}$. Taką funkcję u progu epoki nowożytnej odgrywała przede wszystkim część trzecia Summae Theologiae Tomasza z Akwinu (1225-1274) ${ }^{7}$, studiowanej wnikliwie na wszystkich uniwersyteckich wydziałach teologicznych i w zakonnych studiach generalnych ${ }^{8}$ oraz Rationale Divinorum Officiorum Guillaume’a Duranda (ok. 1230-1296) ${ }^{9}$, będące

SCAVIZZI 1982, s. XV-XVI. O genezie i głównych tendencjach nowożytnej teologii kontrowersyjnej zob.: WALTER 2017, s. 37-42.

4 Takie „krążenie idei” było bardzo charakterystyczne dla wielkich sporów teologicznych, toczonych przez teologów różnych wyznań w XVI wieku i na początku następnego stulecia. Zob.: NELSON BURNETT 2011a.

Zob. np.: PASIERB 1968, s. 17-28; WIT 2005, s. 211-229; NADOLSKI 2008.

IZBICKI 2015, s. IX

TOMASZ Z AKWINU 1974, księga 3, zagadnienie 83, artykuł 3.

INNOCENZO III, 2002, s. 2-419.

DURANDUS 1859, s. 19-22 (lib. I, cap. II: De Altari). 
w pierwszym stuleciu dziejów drukarstwajedną z najczęściej publikowanych książek ${ }^{10}$. Wyrazistą prezentację symboliki ołtarza odnajdowano także $w$ traktacie papieża Innocentego III (Lotario de'Conti di Segni, 1160 lub 1161-1216) De sacro altaris mysterio ${ }^{11}$, zwłaszcza po jego ogłoszeniu drukiem w roku 1534 przez katolickiego apologetę Johannesa Cochläusa (1479-1552) ${ }^{12}$. Tomasz, Durand i Innocenty III nauczali przede wszystkim, że na ołtarzu jest ponawiana krzyżowa Męka Chrystusa, a chleb i wino przeistaczają się w Jego Ciało i Krew, które są ofiarowane Bogu za zbawienie ludzi. Wskutek tego każdy ołtarz powinien być postrzegany jako obraz

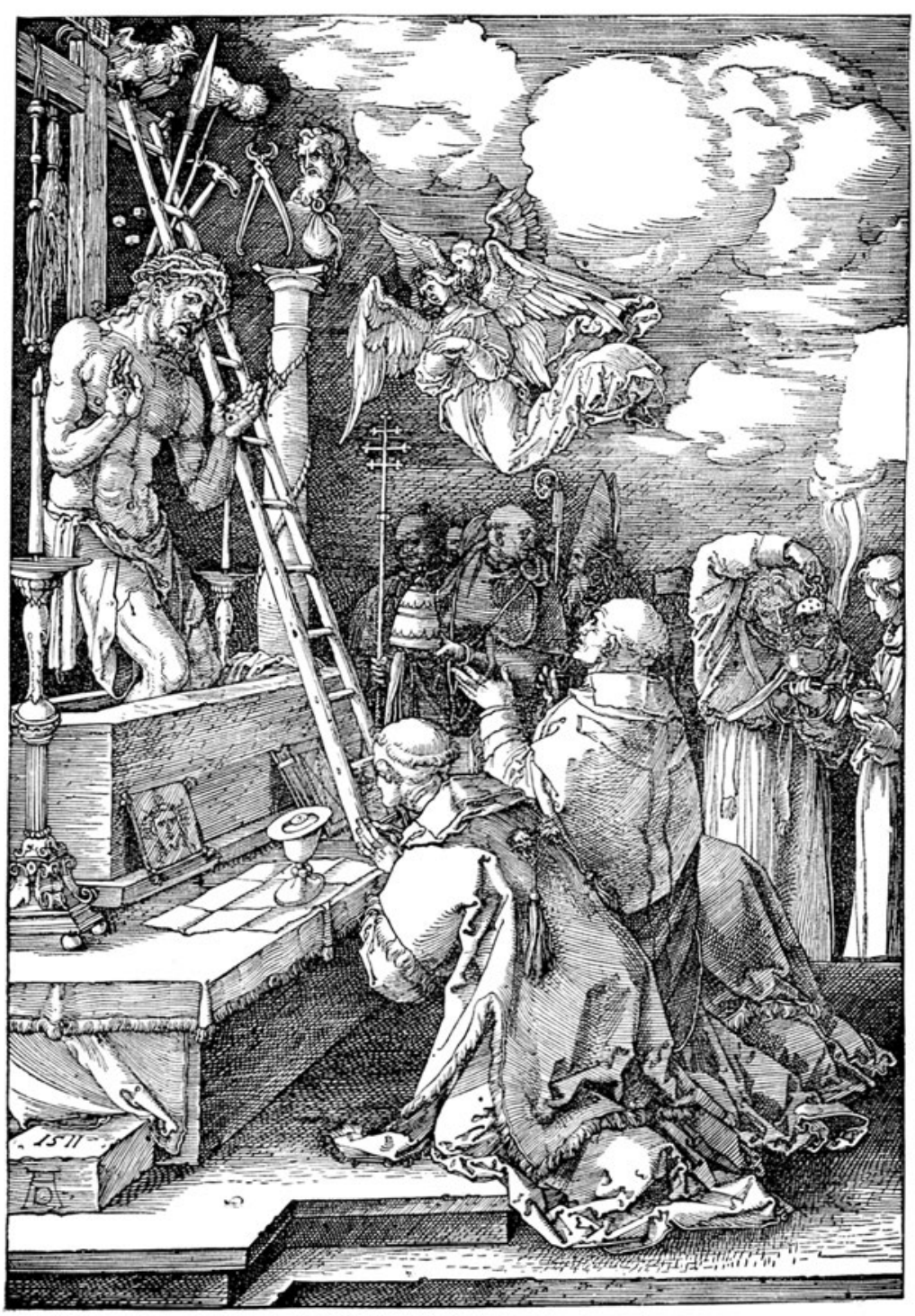




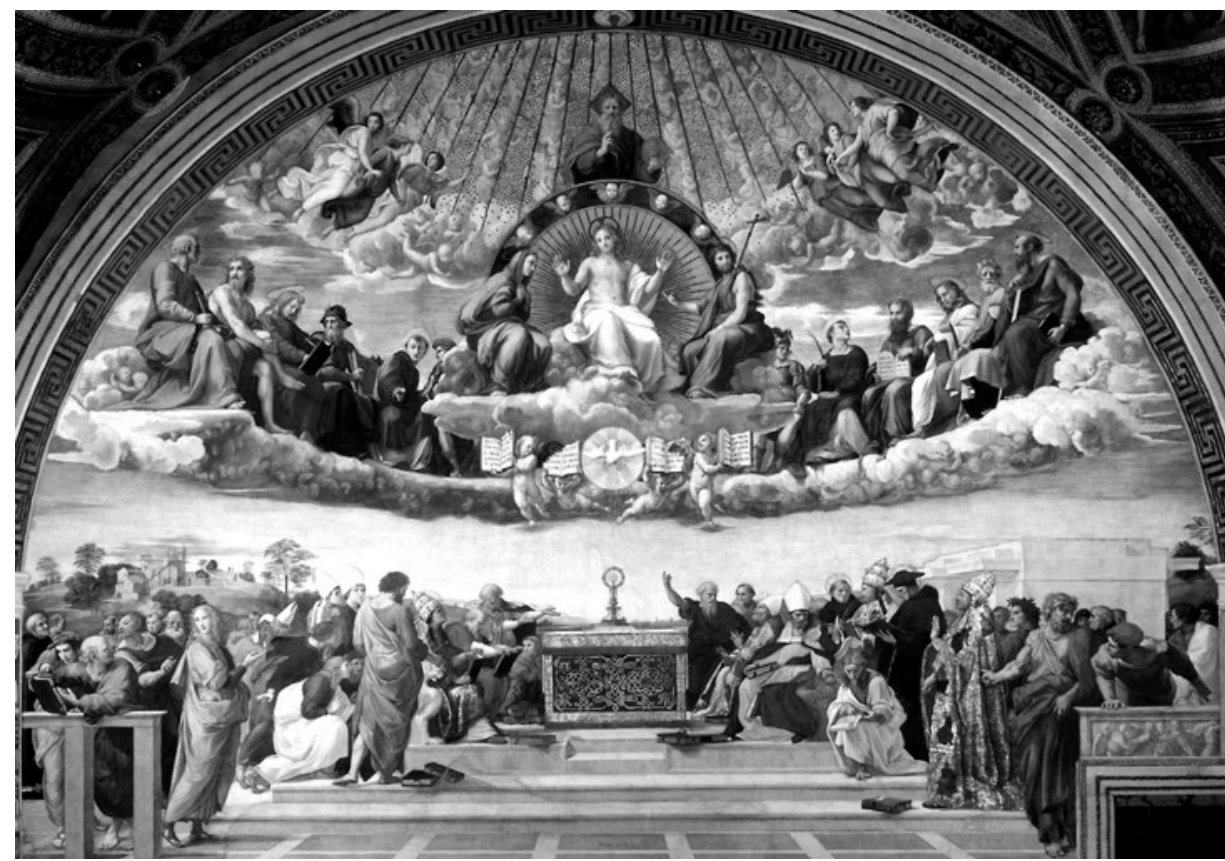

Ołtarza Całopalenia w Świątyni Jerozolimskiej, Krzyża Chrystusa, a także samego Zbawiciela. Pouczali również, że z powodu sprawowania na ołtarzu najświętszego z sakramentów ów sprzęt kościelny staje się sercem świata, jako miejsce łączące ziemię z niebem i wiernych z Bogiem. Dlatego zasługuje on na oznaki czci, takie jak okadzanie go, całowanie i przyklękanie przed nim, a także na bogatą ozdobę $^{13}$. Taka symbolika ołtarza, ukazana wyraziście przez Rafaela (1483-1520) w watykańskiej Dyspucie o Najświętszym Sakramencie (1508-1511) ${ }^{14}$, była przypomina i dodatkowo uzasadniana w licznych opracowywanych przez katolickich pisarzy kompendiach teologicznych i rozprawach apologetycznych oraz w katechizmach i skrutyniach kapłańskich ${ }^{15}$. Odrzucali ją jednak teologowie protestanccy, którzy zakwestionowali najpierw katolicką naukę o Eucharystii, a następnie poróżnili się radyklanie między sobą zarówno w sprawie pojmowania tego sakramentu, jak i kształtowania miejsca do jego sprawowania ${ }^{16}$.

Luter odrzucił wiele zasadniczych elementów katolickiego nauczania o Eucharystii ${ }^{17}$, ale w dalszym ciągu nazywał ją - tak jak Innocenty III - Sakramentem
Rafael, Dysputa

o Najświętszym

Sakramencie,

fresk w Pałacu

Apostolskim

w Watykanie,

1508-1512,

domena publiczna

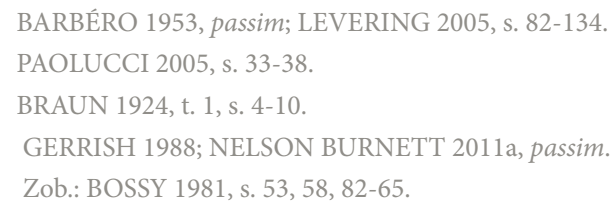


Lucas Cranach

Młodszy, Sakrament

Ołtarza u luteranów,

drzeworytnicza

reprodukcja epitafium

nad grobem Lutra

w kościele zamkowym

w Wittenberdze,

po 1546

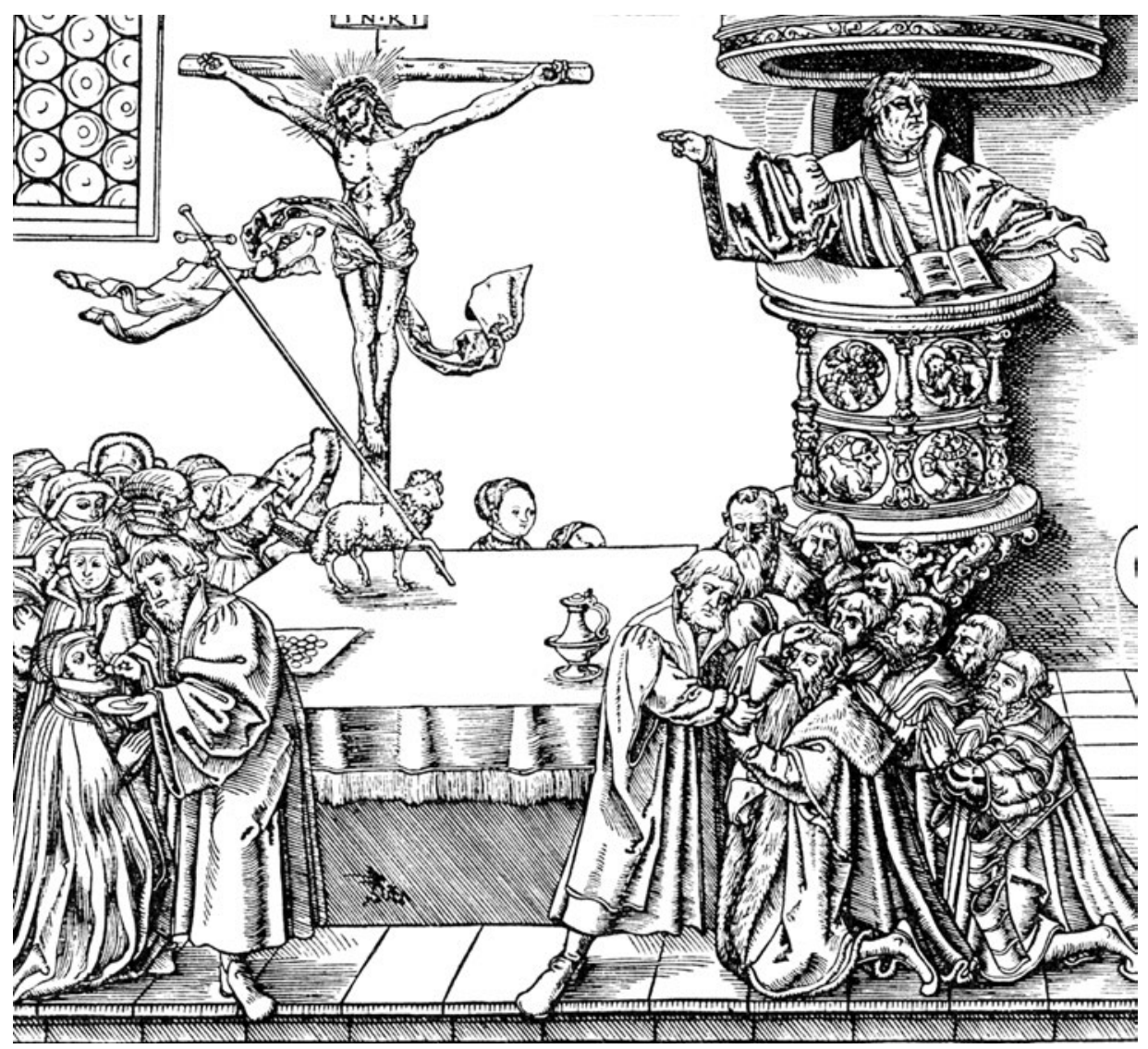

Ołtarza $^{18}$, stosując to określenie m.in. w bardzo poczytnych Der kleine Kathechismus (1529) i Der große Kathechismus (1529) ${ }^{19}$. Jak zauważył Victor A. Shepferd, taka terminologia może budzić zdziwienie, ponieważ „w Starym Testamencie ołtarz był miejscem składania ofiar [...] a Luter odciął się całkowicie od rzymskokatolickiej koncepcji Ofiary Mszy Świętej. Uważał ją za bluźnierstwo, ponieważ przeczyła ona biblijnemu nauczaniu, że Jezus złożył jedyną ofiarę za zbawienie świata (Hbr 10, 10-14). Przywiązanie Lutra do terminu ołtarz postrzegano więc jako niekonsekwencję"20. W odpowiedzi na takie supozycje, formułowane m.in. przez Andreasa Karlstadta (1486-1541) $)^{21}$, Luter przypomniał jednak w rozprawie Wider die himmlischen Propheten, von den Bilderund Sakrament, wydanej w roku 1525, że „jak zaświadcza Jozue (Joz. 22, 10-34), kiedy plemiona Rubena, Gada

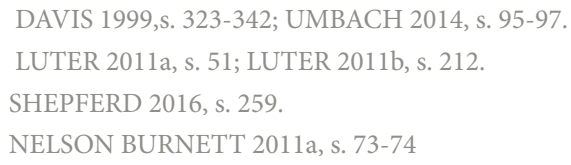


i Manassesa zbudowały wielki ołtarz przy Jordanie, cały Izrael wzburzył się tym uczynkiem i z wielką troską skierował do nich posłańców, którzy mieli pouczyć ich, że ołtarz powinien zostać zburzony, ponieważ został wzniesiony wbrew zakazowi Bożemu, obowiązującemu rzeczywiście w owym czasie. Posłańcy zgodzili się jednak na zachowanie ołtarza, gdy usłyszeli, że nie został on wzniesiony na całopalenie ani ofiary, ale na świadectwo". Wypowiedź ta miała dowodzić, że starotestamentalne ołtarze były nie tylko miejscem składania ofiar, ale także „świadectwem naszym, że nasz Pan jest Bogiem" (Joz 22, 34), czyli swoistym wyznaniem wiary ${ }^{22}$. Uświadomienie sobie tej drugiej funkcji ołtarza przez luteranów pozwoliło im nie tylko uzasadnić ich przywiązanie do owego określenia, ale przyczyniło się także do podejmowania przez nich kontemplacji ołtarza, rozwijanej m.in. przez Johanna Gerharda (15821637) w bardzo ostrożny sposób, aby nie upodobniła się ona do katolickiej „bałwochwalczej" czci²3.

Zasadniczą zmianę w postrzeganiu symboliki ołtarza wprowadził za to jeden z oponentów Lutra, Martin Butzer (1491-1551), który w roku 1524 zainicjował radykalną reformę porządku kościelnego w Strasburgu. Jednym z jej głównych założeń było całkowite wyrugowanie z umysłów wiernych „papistowskiej” koncepcji Eucharystii jako ofiary, co według tego reformatora wymagało zaprzestania sprawowania jej na miejscach, naśladujących starożytne ołtarze ofiarne. Butzer głosił, że jeśli Eucharystia jest pamiątką Wieczerzy Pańskiej, powinna być - tak jak ona - odprawiana na zwykłym drewnianym stole ${ }^{24}$. Skłonił także duchowieństwo strasburskie do podpisania deklaracji, że „Wieczerza Pańska nie będzie już nigdy nazywa mszą, a Stół Pański ołtarzem", nadając swojej reformie także semantyczny charakter ${ }^{25}$. Tę terminologiczną zmianę uzasadnił gruntownie w rozprawce Grund und Ursach aus Gottlicher Schrift, wydanej w roku $1524^{26}$, która odegrała kluczową rolę w potępianiu przez liczne wspólnoty protestanckie terminu ołtarz i afirmowaniu określenia Stół Pański, zapożyczonego od apostoła Pawła (1 Kor 10, 21) 27. Takie określenie przyjęto w licznych porządkach kościelnych wprowadzonych w różnych miastach niemieckich (np. porządek kościoła św. Anny w Augsburgu, opracowany przez Jörga Vischera i Johannesa Platnera w roku 1531) ${ }^{28}$. Propagował go również Jan Kalwin (1509-1564) w Institutione religionis christianae, wydanej w ostatecznej redakcji

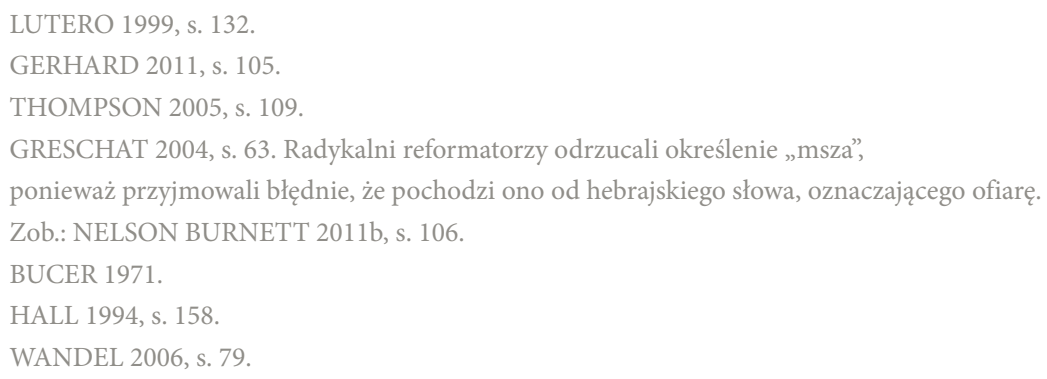


w roku 1559, stwierdzając, że „Pan dał nam stół, na którym mamy ucztować, a nie ołtarz, na którym mają być składane ofiary. Nie ordynował on też kapłanów do składania ofiar, ale ministrów do rozdawania ludowi Świętego Posiłku"29. Określenie Stół Pański zastąpiło więc ołtarz w dokumentach Kościoła ewangelicko-reformowanego, takich jak genewski porządek nabożeństwa z roku $1541^{30}$ lub uchwały niderlandzkich synodów narodowych, odbytych w Dodrechcie w roku 1574 i w Hadze w roku 1586. Uchwały te zabraniały ponadto klękania przy Stole Pańskim, co mogłoby sugerować, że oddaje się mu bałwochwalczą cześć, podobną do „papistowskiego” nabożeństwa dla ołtarza ${ }^{31}$. Protestanci okazywali jednak szacunek Stołowi Pańskiemu, ze względu na sprawowane przy nim Święte Tajemnice. Znalazło to wyraz w konsekwentnym pisaniu nazwy tego sprzętu wielką literą, a szerszego uzasadnienia doczekało się w przepisach liturgicznych niderlandzkich remonstrantów, opracowanych w roku 1633. Nakazywały one celebransowi pouczyć przed komunią wiernych słowami: „Osądźmy zatem, czy uważamy siebie za gotowych do przystąpienia do tego Świętego Stołu, nie jak do zwyczajnego stołu, ale jak do stołu, który jako jedyny został uświęcony i naznaczony przez wspaniały dar Jezusa Chrystusa, za który nigdy nie będziemy w stanie złożyć należytego podziękowania" 32 .

Po wyjeździe na Wyspy Brytyjskie w roku 1541 Butzer propagował tam także koncepcję zastąpienia ołtarza Stołem Pańskim, wpływając między innymi na zastosowanie takiego terminu w Form of Prayers, opracowanej dla Kościoła szkockiego przez Johna Knoxa (1505-1572) w roku 1556 ${ }^{33}$. Niemiecki reformator przekonał też do swojej koncepcji niektórych anglikańskich hierarchów, a zwłaszcza biskupa londyńskiego i westminsterskiego Nicholasa Ridleya (1505-1575), który w roku 1547 ogłosił rozprawkę Reasons Why the Lord's Board Should Rather Be After the Form of a Table Then of an Altar ${ }^{34}$. Problem zarysowany w tej pracy stał się na długie lata jedną z najważniejszych kontrowersji dzielących anglikańskie stronnictwa purytanów i rytualistów, co zaowocowało między innymi powstaniem dwóch najokazalszych nowożytnych traktatów poświęconych symbolice ołtarza ${ }^{35}$. Pierwszy z nich, ogłoszony w roku 1637 przez purytanina, biskupa Lincoln Johna Williamsa (1582-1650) pod tytułem Holy Table. Name and Thing, uzasadniał ową nomenklaturę nie tylko

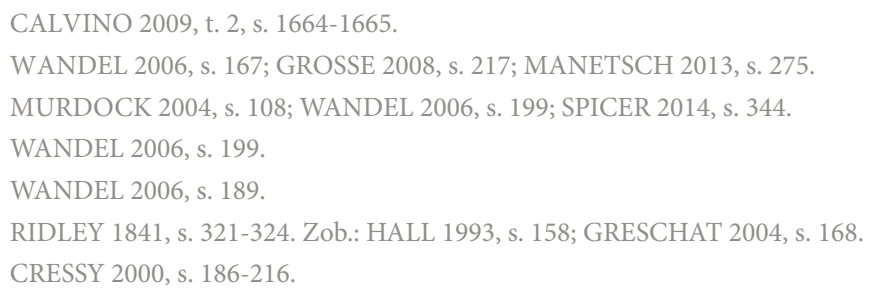


poprzez negowanie ofiarniczego charakteru Eucharystii, ale także za pomocą argumentów historycznych. Głosił on bowiem, że miejsce jej pierwszego sprawowania zostało opisane jako stół już przez ewangelistów Mateusza (Mt 26.20) i Łuksza (Łk 22, 14), zaś stwierdzenia, że należy odprawiać ją na ołtarzu pojawiły się w pismach Ojców Kościoła dopiero po ponad dwustu latach, kiedy czystość nauki chrześcijańskiej została skażona elementami przejmowanymi z kultury pogan ${ }^{36}$.

Zupełnie odmienne spojrzenie na miejsce sprawowania Eucharystii zaproponował w tym samym roku, skłaniający się ku rytualizmowi, były kapelan Williams John Pocklington (zm. 1642) w traktacie Altare christianum or the Dead Vicar's Plea. Wskazał w nim pisma wczesnochrześcijańskie z początku II wieku (a więc nieomal z czasów apostolskich), w których używano określenia ołtarz. Przede wszystkim suponował jednak propagatorom Stołu Pańskiego, że stosując tę prozaiczną nazwę, starają się umniejszyć znaczenie tajemnic, dokonujących się na ołtarzu i czyniących z tego sprzętu „najświętsze miejsce pod sklepieniem Nieba”. Głosił bowiem, że jest on nie tylko miejscem, na którym sprawuje się pamiątkę Wieczerzy Pańskiej, ale także „tronem (chaire of state) Boga na ziemi”, niezależnie od tego czy uobecnienie Chrystusa w Eucharystii dokonuje się poprzez transsubstancjację chleba i wina (którą odrzucał) czy też w sposób duchowy ${ }^{37}$. Podobną symbolikę ołtarza propagował arcybiskup Canterbury William Laud (1573-1645), który w swoich kazaniach powtarzał „Ołtarz, ołtarz, wyłącznie ołtarz!”. Swymi rozporządzeniami, wydanymi na przełomie lat trzydziestych i czterdziestych wieku XVII, przywrócił on stosowanie tego terminu w tekstach liturgicznych. Było to jednym z najważniejszych przejawów powrotu anglikanizmu na via media pomiędzy katolicyzmem i reformacją, zainicjowanego przez tego hierarchę ${ }^{38}$.

\section{Uzasadnienie świętości ołtarza}

Kolejną kontrowersję na temat ołtarza, dzielącą katolików i protestantów, opisał znakomicie senior Jednoty Braterskiej Jan Amos Komeński (1592-1670) w Historia persecutionum Ecclaesiae Bohemicae, wydanej w roku 1648. Duchowny ów zarzucił katolikom, że przejmując w latach dwudziestych wieku XVII kościoły utrakwistów i luteranów w Królestwie Czeskim, nie mieli oporów przed niszczeniem znajdujących się w nich ołtarzy, głosząc iż nie są one miejscami świętymi, ponieważ nie zostały uroczyście konsekrowane. „Przesądowi” temu przeciwstawił opinię, że w świetle

WILLIAMS 1637, passim. Zob. też: CRESSY 2000, s. 192-193.

POCKLINGTON 2002, passim; fragmenty przywołane w tym artykule in extenso - s. 102.

Zob.: CRESSY 2000, s. 194; PARRY 2006, s. 27-38; LANE 2013, s. 62-64.

38 CRESSY 2000, s. 194; FINCHAM 2001, s. 922-928; PARRY 2006, s. 13, 135. 
nauczanie Biblii (1 Tm 4, 15) wszystko zostaje uświęcone wyłącznie poprzez wiarę i modlitwę, a ołtarze - w szczególny sposób poprzez to, że sprawuje się przy nich Eucharystię i rozdziela Komunię pod dwiema postaciami ${ }^{39}$.

W tradycji Kościoła katolickiego poświęcenie ołtarza, czyli „przeznaczenie go na miejsce sprawowania Eucharystii i wyłączenie go z użytkowania do jakichkolwiek innych celów", miało formę skomplikowanego rytu, sprawowanego przez biskupa, obejmującego obok długich modlitw znaki widzialne, mianowicie namaszczenie krzyżmem i okadzenie. Wszystkie te starodawne ceremonie zostały skrzętnie zachowane w typicznym wydaniu Pontificalis Romani, ogłoszonym w roku 1596 przez papieża Klemensa VIII (Ippolito Aldobrandini, 1536-1605) ${ }^{40}$. Takie działanie redaktorów pontyfikału miało wyraźnie kontrreformacyjną wymowę. W drugiej połowie wieku XVI Piotr Kanizjusz (1521-1597) i inni katoliccy apologeci prezentowali konsekwentnie ryt konsekracji ołtarza jako jedną z katolickich wspaniałych ceremonii, pobudzających pobożność wiernych w odróżnieniu od skromnych protestanckich obrzędów, studzących w laikach uwielbienie dla Bożych Tajemnic ${ }^{41}$.

Uroczysty ryt poświęcenia materialnych przedmiotów został radykalnie odrzucony przez Lutra jako „urąganie, i czyste błazeństwo, i oszustwo” w Schmalkaldische Artikel, podpisanych w roku 1537 przez licznych teologów i duchownych, działających w Rzeszy ${ }^{42}$. W kazaniu wygłoszonym podczas inauguracji nowego kościoła zamkowego w Torgawie w roku 1544 reformator ów wskazał za to „sposób, w jaki kościół powinien być po chrześcijańsku pobłogosławiony, nie tak jak kościoły papistów, które ich biskupi namaszczają krzyżmem i kropią wodą, ale zgodnie z wolą Bożą poprzez słuchanie i głoszenie Słowa Bożego" ${ }^{\text {‘3 }}$. Luter nie zasugerował żadnego „właściwego i chrześcijańskiego” sposobu dedykowania ołtarzy. W Kościele ewangelicko-augsburskim „wyczytano” jednak z czasem z jego homilii, że tak jak kościół jest uświęcany przez pierwsze kazanie, tak ołtarz dostępuje uświęcenia poprzez odprawienie na nim pierwszej Eucharystii. Taki pogląd został ugruntowany poprzez drukowane opisy ceremonii inauguracji wielkich świątyń protestanckich w Rzeszy, dokonanych pod koniec wieku XVI i na początku następnego stulecia. Na obszarze języka niemieckiego wydawnictwa te nabrały charakteru quasi-rytuałów, określających zasady „poświęcania” kościołów protestanckich i najważniejszych elementów ich wyposażenia ${ }^{44}$.

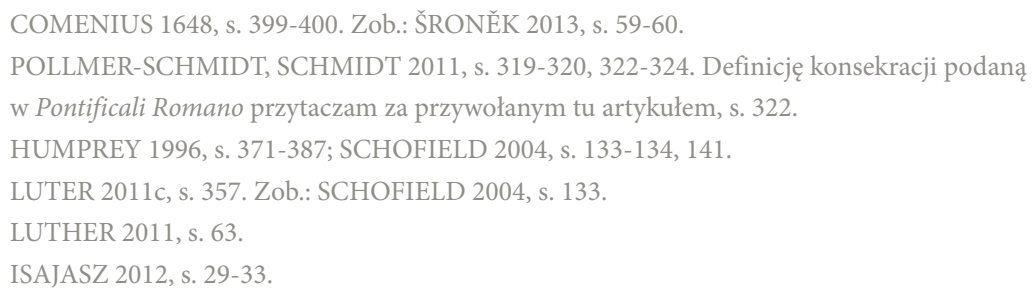


Poglądy luteranów podzielał Kalwin, który pouczał w Institutione religionis christianae, iż kościoły chrześcijańskie są uświęcane przez modlitwy wiernych, głoszenie Słowa Bożego i odprawiane się w nich święte obrzędy" ${ }^{45}$. Dlatego w Les actes du Concille de Trente avec le remedecontre la poison, wydanych w roku 1547, głosił, że konsekrowanie ołtarzy jest po pierwsze zbędne, a po drugie szkodliwe, ponieważ prowokuje lud do oddawania bałwochwalczej czci temu sprzętowi ${ }^{46}$. Obawa przed takim zgorszeniem, sprawiła być może, że w siedemnastowiecznych drukach kalwinistów, upamiętniających inaugurację ich kościołów, odnotowywano skrzętnie treść pierwszego kazania, ale nie wspominano o Eucharystii celebrowanej na nowym Stole Pańskim ${ }^{47}$.

Angielscy purytanie podchodzili do kwestii poświęcenia ołtarza tak samo jak luteranie i kalwiniści, kierując się przede wszystkim rozporządzeniem wydanym w imieniu króla Edwarda VI (1537-1953) w roku 1547, które głosiło, że „święcenie ołtarzy nie jest do niczego potrzebne, ale jest wyłącznie przesądem"48. Rytualiści utrzymywali zaś, że sprzęt ten powinien być uroczyście konsekrowany, ponieważ tylko dzięki temu rytowi stanie się on godnym tronem dla Eucharystii. Katolicki charakter tego przekonania wyraziście potwierdził arcybiskup Laud, opracowując ryt poświęcenia ołtarza, powtarzający w nieco uproszczony sposób obrzędy z Pontyfikału rzymskiego ${ }^{49}$. Podobna formuła konsekracyjna, została wprowadzona do agendy króla Karola I (1600-1649), opracowanej w roku 1640. Chociaż Kościół anglikański nie przyjął nigdy oficjalnie tej księgi, zawarty w niej obrzęd poświęcenia ołtarza stał się wzorem odprawiania owej „nie utwierdzonej ceremonii” dla licznych biskupów - rytualistów ${ }^{50}$.

\section{Liczba oltarzy w kościele}

Tomasz z Akwinu ugruntował w Summa Theologiae przekonanie sięgające pierwszych wieków chrześcijaństwa, że „gmach w którym celebrujemy ten sakrament [Eucharystii] symbolizuje Kościół [...] ołtarz zaś jest symbolem samego Chrystusa" ${ }^{11}$. Ta wzniosła symbolika była w pełni czytelna tylko w przypadku, kiedy w kościele znajdował się wyłącznie jeden ołtarz, przy którym odprawiano jedno nabożeństwo dla całej wspólnoty wiernych związanych z tym budynkiem. W Kościele rzymskim

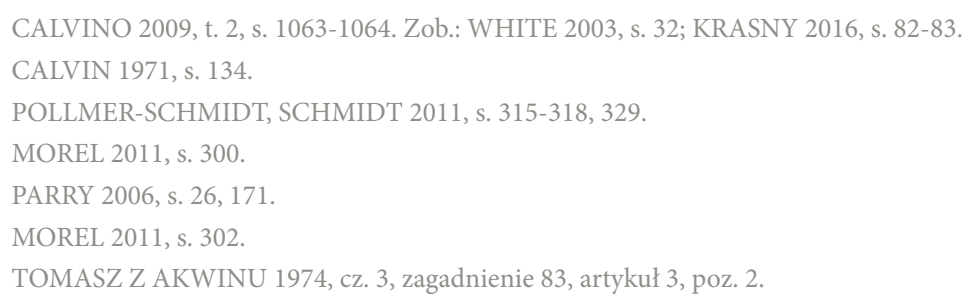




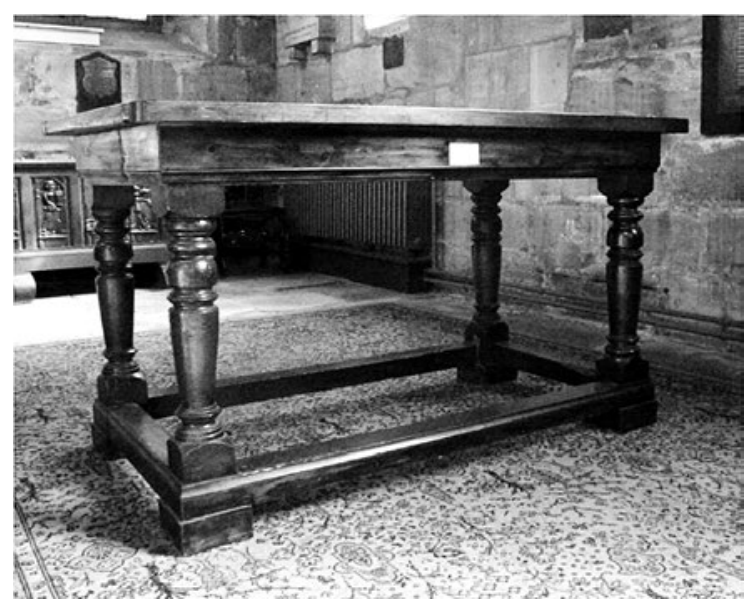

rozpowszechniła się jednak praktyka umieszczania w świątyniach ołtarzy bocznych, odnotowana już w VI stuleciu (il. 4) ${ }^{52}$. Ołtarze takie miały zapewnić licznym kapłanom, zgromadzonym przede wszystkim przy wielkich kościołach miejskich i w klasztorach, równoczesne odprawienie wielu „mszy prywatnych”, a także były erygowane jako wyraz pobożności różnych osób i korporacji ${ }^{53}$.

Zasadę, że w kościele może znajdować się tylko jeden ołtarz, zachowywał za to skrzętnie Kościół wschodni. Metropolita kijowski Piotr Mohyła (1596-

Stół Pański w kościele Holy Trinity w Berwick-upon-Tyre, około 1650. Według: SPICER 2014

1647) przywołał w roku $1644 \mathrm{w}$ dziele $\Lambda i \theta o \varsigma$ abo kamień z procy Cerkwie świętej prawosławnej ruskiej stan ten jako dowód prawowierności owej wspólnoty. Zarzucił równocześnie katolikom, że mnożąc liczbę ołtarzy i mszy w swoich kościołach, sieją oni zamęt w umysłach wiernych ${ }^{54}$. Podobną opinię wyraził Blaise Pascal (16231662), szydząc w ogłoszonej w roku 1657 dziewiątej Lettre provinciale, że wierny wchodzący w niedzielę do katedry Notre-Dame w Paryżu może w jednej chwili wysłuchać różnych części mszy, odprawianych przy poszczególnych ołtarzach i tym samym wypełnić bardzo szybko świąteczny obowiązek uczestnictwa w Eucharystii ${ }^{55}$.

Wszelkie reformy liturgii eucharystycznej podejmowane na przełomie średniowiecza i epoki nowożytnej, zmierzały do przywrócenia jej wspólnotowego charakte$\mathrm{ru}^{56}$, czemu miało służyć pozostawienie tylko jednego ołtarza w kościele. Działanie takie podjęli już husyci, którzy w manifeście doktrynalnym, sformułowanym w roku 1420 głosili, że „w jednym kościele [...] nie należy odprawiać więcej mszy, niż jedną [...] i w kościele nie powinno być więcej ołtarzy niż jeden, przeznaczony do odprawiania tej jednej mszy" ${ }^{37}$.

W opublikowanej w roku 1521 rozprawie De abroganda missa privata Luter potępił zdecydowanie „papistowski” zwyczaj odprawiania „mszy prywatnych”, stwierdzając jednocześnie „bezużyteczność” ołtarzy bocznych i pouczając, że środki przeznaczone na ich utrzymanie i ozdobę powinny zostać raczej przekazane biednym ${ }^{58}$. Niszczycielska sugestia zawarta w tym pouczeniu została jednoznacznie odczytana

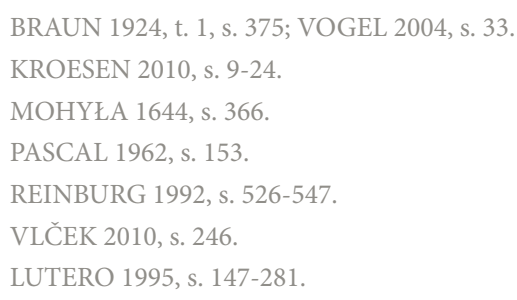


przez przeora augustianów w Wittenberdze - Gabriela Zwillinga (1487-1558), który 10 stycznia 1522 polecił usunąć z klasztornej kaplicy ołtarze boczne i spalić ich nastawy ${ }^{59}$. Po czternastu dniach w Kastenordnung, opracowanej dla tego miasta pod kierunkiem Karlstadta, orzeczono, że wszystkie ołtarze boczne „mają zostać usunięte, aby uniknąć bałwochwalstwa ${ }^{60}$. Luter wstrzymał się wszakże $\mathrm{z}$ jednoznacznym poparciem takich działań, obawiając się że mogą one ze względu na swój radykalizm zgorszyć „słabszych w wierze” ${ }^{61}$.

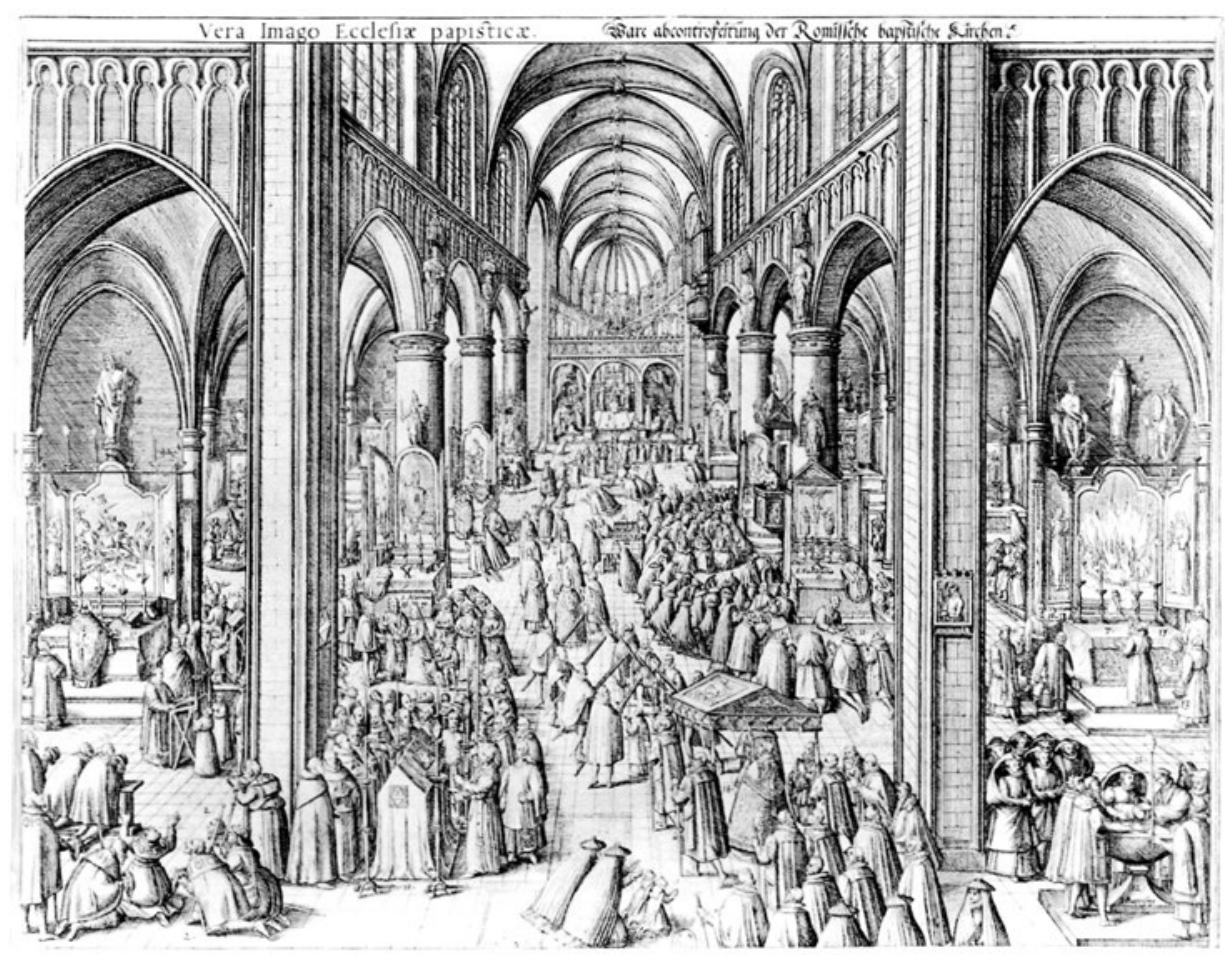

Zdecydowane pouczenie, że „należy usunąć z kościoła wszystkie ołtarze z wyjątkiem jednego" (il. 5) sformułował pierwszy luterański biskup Zelandii Peder Palladius (1503-1560) w opracowanym około roku 1540 En Visitatsbok ${ }^{62}$, wykorzystywanym powszechnie jako podręcznik reformowania życia religijnego w parafiach na terenie
Prawdziwy obraz kościoła papistowskiego, miedzioryt, około 1600

59 SCAVIZZI 1982, s. 53; SCHILLING 2017, s. 279.

60 LIETZMANN 1907, s. 5; NEUSER 1968, s. 166; SCAVIZZI 1982, s. 56.

61 ULLMANN 1999, s. 279. Ostrożne stanowisko Lutra było podtrzymywane przez większość luterańskich władców na terenie Rzeszy. Nakazy usuwania ołtarzy bocznych zostały wydane wyłącznie we Wschodniej Fryzji, Meklemburgii i w Weimarze. Zob.: SPICER 2014, s. 336.

62 PALLADIUS 2012, s. 39. Zob.: GRANE 1990, s. 177; STAECKER 2012, s. 266. 


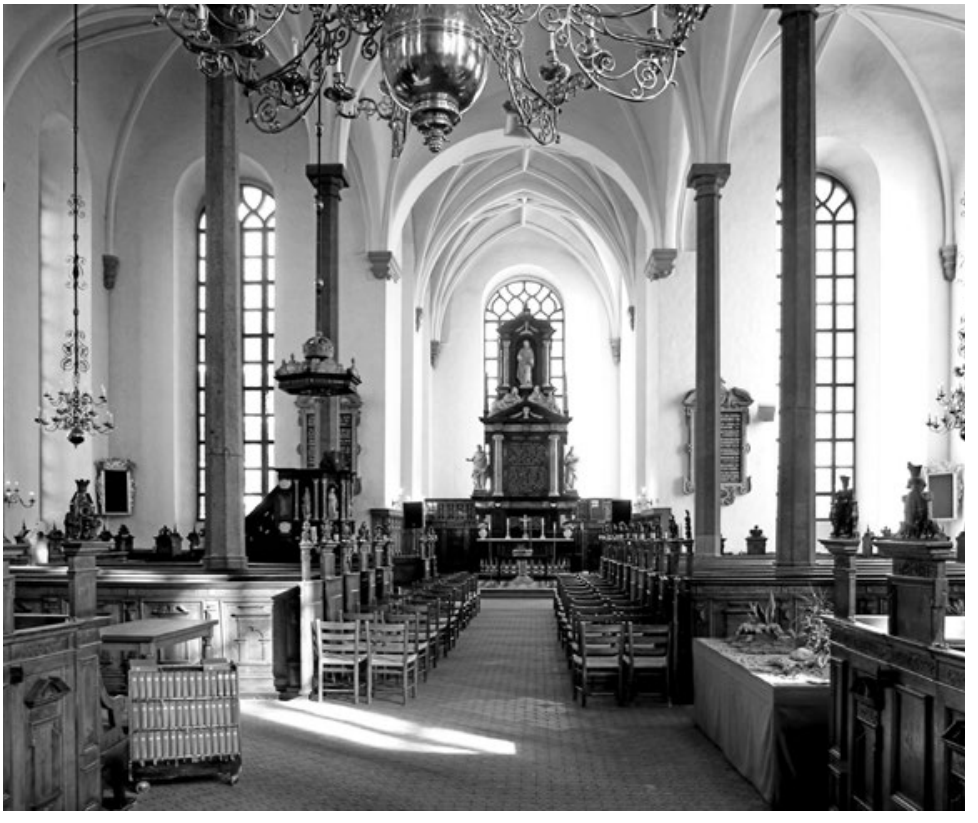

Kościół Heliga Trefaldighet w Kristanstadt, ukończony 1628. fot. David Castor, domena publiczna
Danii i innych krajów skandynawskich ${ }^{63}$. Duchowny ten wykazał się także niemałą pomysłowością w wyszukaniu pożytecznych zastosowań dla elementów z „bezużytecznych" ołtarzy. Wyjęte z nich obrazy nakazał rozwiesić na ścianach jako tablice do pouczania ludu, elementy konstrukcyjne nastaw polecał wykorzystać do budowy ambon, a obrusy - przerobić na koszule dla biednych i bandaże dla chorych ${ }^{64}$.

Jeszcze bardziej wrogo odnosił się do ołtarzy bocznych Kalwin ${ }^{65}$, stwierdzając, że sprzęty te rzadko służyły do sprawowania liturgii, stając się przede wszystkim przedmiotem prywatnego nabożeństwa wiernych.

$\begin{array}{ll}63 & \text { RILEY 2008, s. 487; SCHWARZ LAUSTEN 2012, s. 19-24. } \\ 64 & \text { PALLADIUS 2012, s. 39; JOHANNSEN 2002, s. 226-227. } \\ 65 & \text { Za czasów Kalwina usunięto z kościołów genewskich } \\ & \text { wszystkie ołtarze, wykorzystujące kamienie } \\ & \text { z ich rozbiórki m.in. do brukowania dróg. } \\ & \text { Zob.: GROSSE 2008, s. 96-103. }\end{array}$

Prawdziwy obraz kościoła apostolskiego (tzn. ewangelickiego), miedzioryt, około 1600

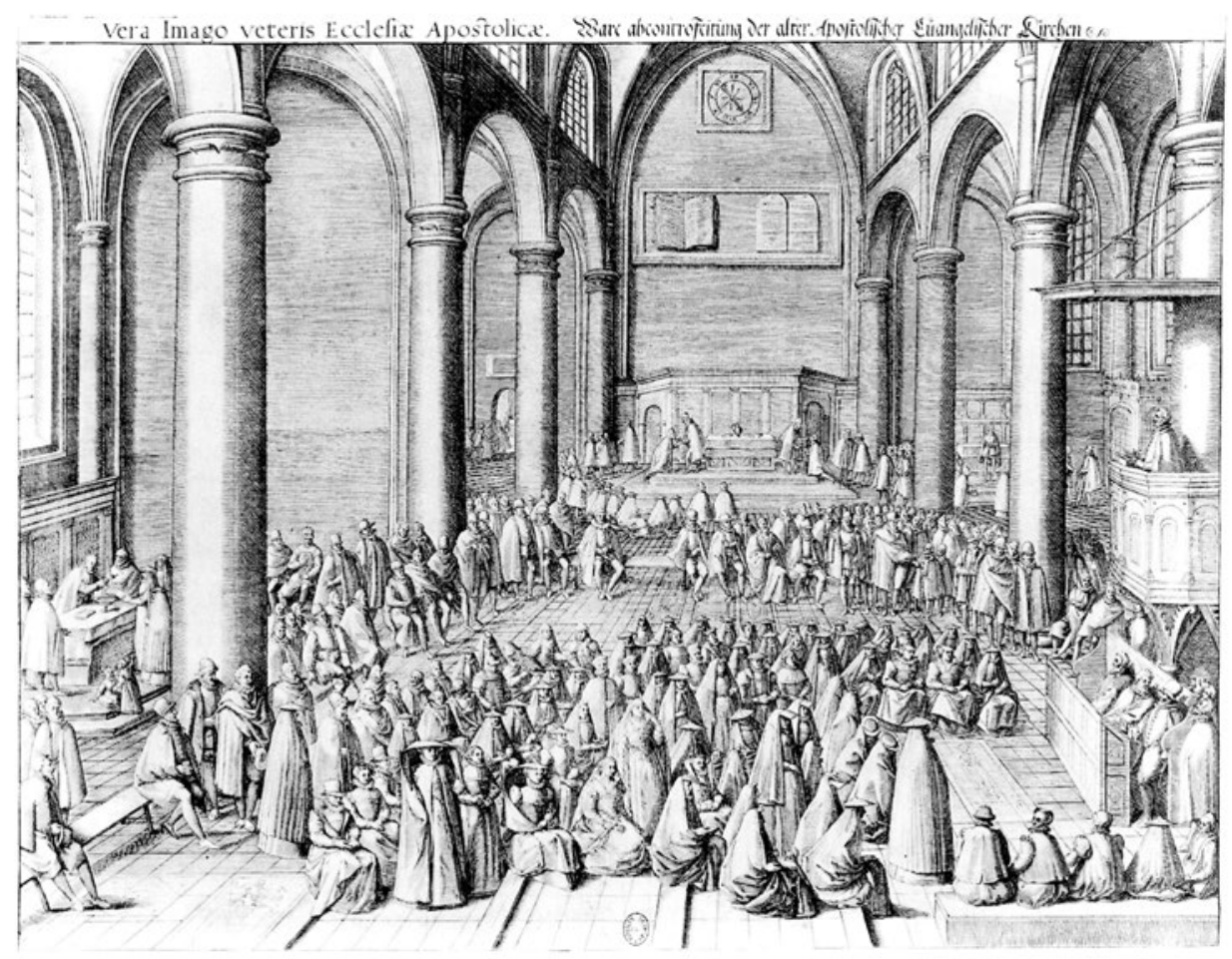


Reformator głosił, że chwała Pańska nie może być przenoszona na Jego ołtarz, a zatem „papistowskie” ołtarze muszą być usunięte, ponieważ prowokują grzech bałwochwalstwa ${ }^{66}$. Wszystkie porządki kościelne kalwinistów dopuszczały więc używanie w kościołach tylko jednego Stołu Pańskiego, a wiele spośród nich pozwalało wystawiać go tylko na czas sprawowania czynności liturgicznych (il. 7) ${ }^{67}$. Autorzy anglikańskich traktatów, poświęconych ołtarzowi przyjmowali też za rzecz oczywistą, że w jednym kościele może znajdować się tylko jeden taki sprzęt, wokół którego powinno jednoczyć się liturgiczne zgromadzenie wiernych ${ }^{68}$.

Katolicy podtrzymywali zaś konsekwentnie odmienną tradycję swojego Kościoła. Podczas dziesiątej sesji Soboru Trydenckiego, 26 lipca 1547, uznano za heretycką i niezgodną z praktyką Kościoła katolickiego opinię, że „msze prywatne są niewłaściwe i mają być zniesione, a jednego dnia w jednym kościele może być odprawiana tylko jedna" ${ }^{69}$. Orzeczenie to oznaczało również potępienie dla koncepcji rezygnowania z ołtarzy bocznych, czego wymownym dowodem było wpisanie w roku 1583 do Indeksu Ksiąg Zakazanych traktatu Leona Battisty Albertiego (1404-1472) De re aedificatoria libri decem. Przyczyną takiego wyroku było zwarte $\mathrm{w}$ tym dziele jedno zdanie, wychwalające dostojną prostotę bazylik chrześcijan żyjących w starożytności, którzy „posiadali w owych czasach jeden tylko ołtarz, przed którym zbierali

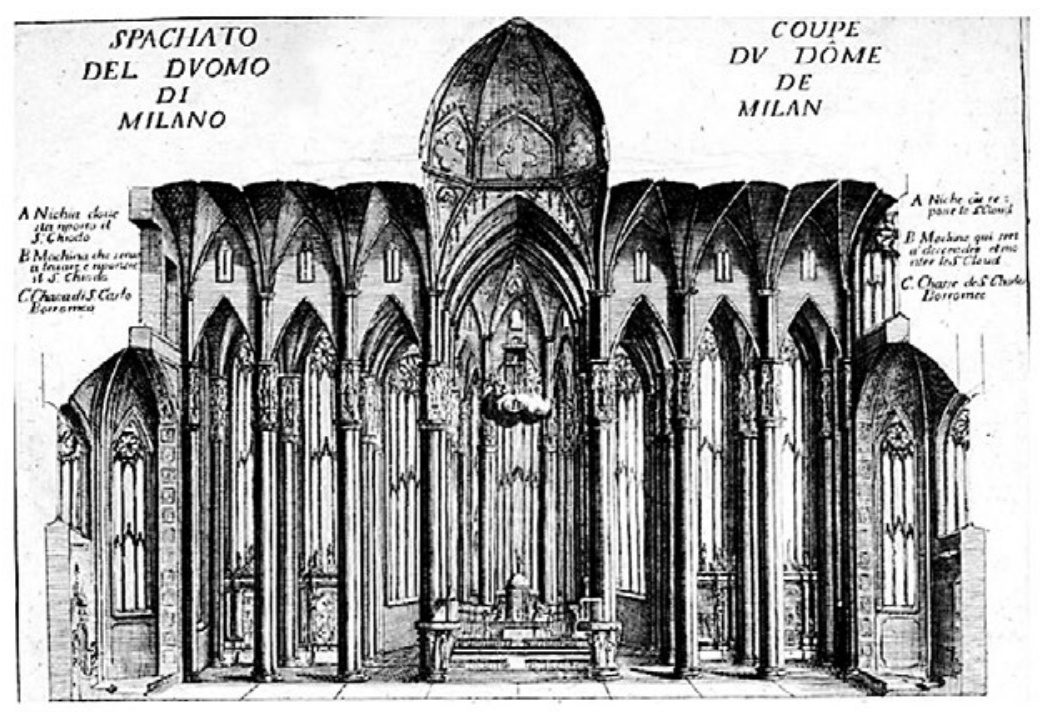




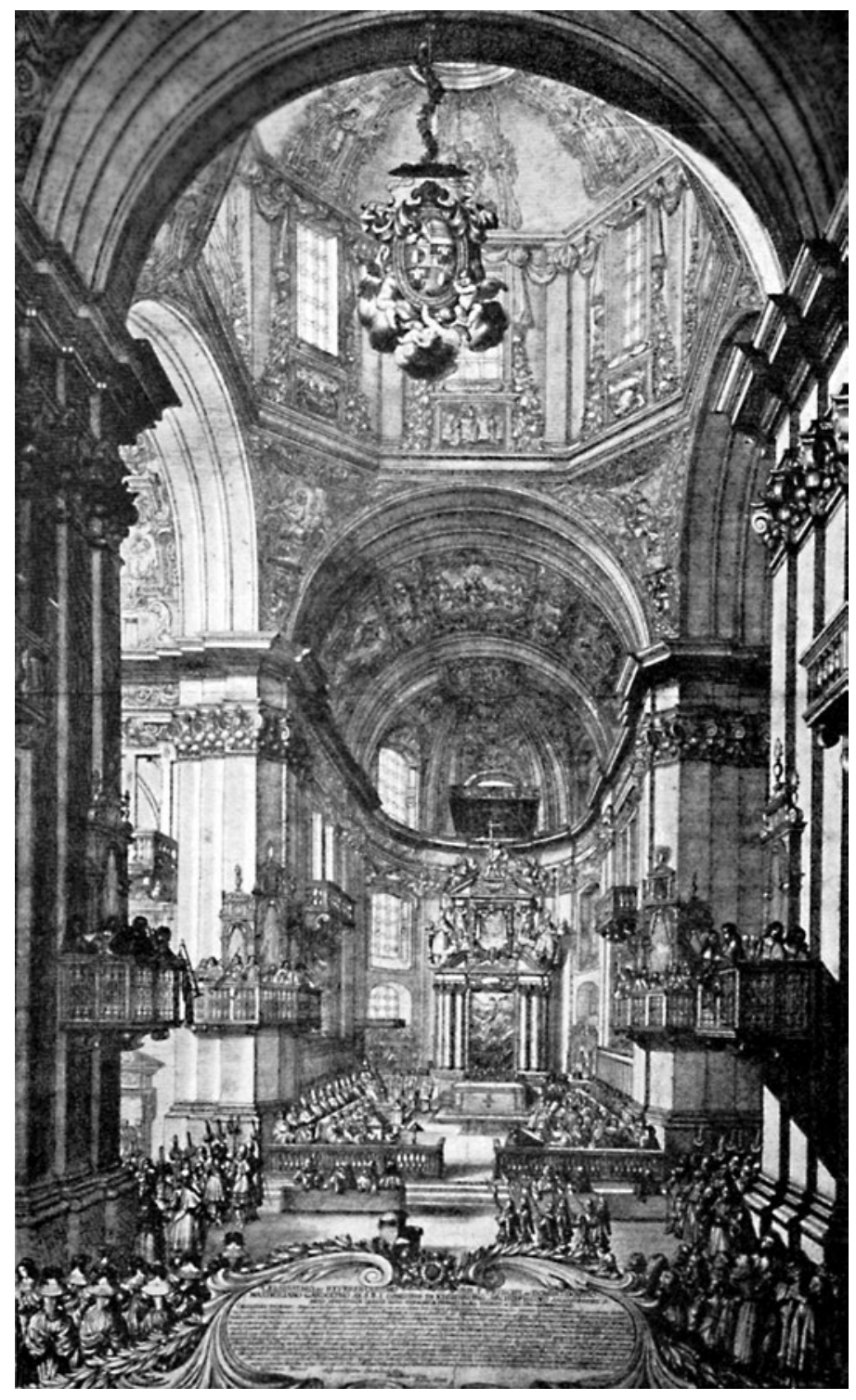

Melchior Küsel, Msza pontyfikalna w katedrze w Salzburgu, miedzioryt, 1631 się raz dziennie dla złożenia jednej ofiary" i potępiające średniowiecznych kapłanów za to, że „wszystko zatłoczyli ołtarzami" ${ }^{\prime 20}$.

Równocześnie jednak starano się uwypuklić symbolikę ołtarza głównego jako obrazu Chrystusa, gromadzącego wokół siebie Kościół, podtrzymując konsekwentnie zwyczaj odprawiania przy tym ołtarzu uroczystych mszy dla całej wspólnoty parafialnej, „zgodnie z praktyką przyjętą w świątyniach rzymskich"71. Architektoniczną formułę uwypuklenia nadzwyczajnej godności ołtarza głównego zaproponował arcybiskup mediolański Karol Boromeusz (1538-1584), pouczając w Instrucionibus fabricae et supellectilis ecclesiasticae, wydanych w roku 1577, że ołtarze boczne powinny być odpowiednio oddalone od ołtarza głównego i ustępować mu wyraźnie rozmiarami i okazałością oprawy architektonicznej (il. $8)^{72}$. Hierarcha ów zalecał również zachowanie odpowiednio dużego dystansu pomiędzy poszczególnymi ołtarzami bocznymi, aby kapłan sprawujący liturgię przy jednym ołtarzu, nie przeszkadzał innemu duchownemu, celebrującemu przy innym, co wyglądałoby bardzo niestosownie"73.

\section{Usytuowanie i ksztalt ołtarza (głównego)}

Kościół katolicki trzymał się wiernie „starodawnej” zasady sytuowania ołtarza głównego w wyodrębnionym prezbiterium, w którym w czasie celebrowania Eucharystii mogli przebywać wyłącznie duchowni (il. 9) ${ }^{74}$. Boromeusz stwierdził w Instructionibus, że ta część kościoła musi być wyniesiona ponad poziom posadzki nawy głównej i oddzielona

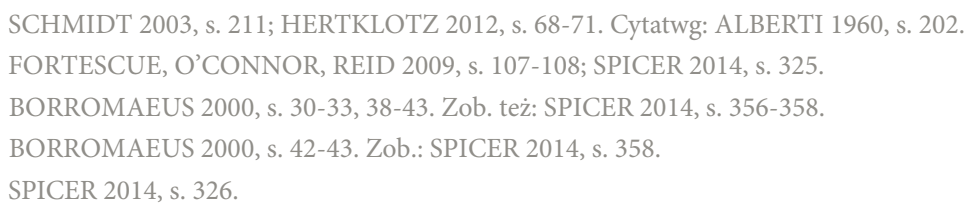




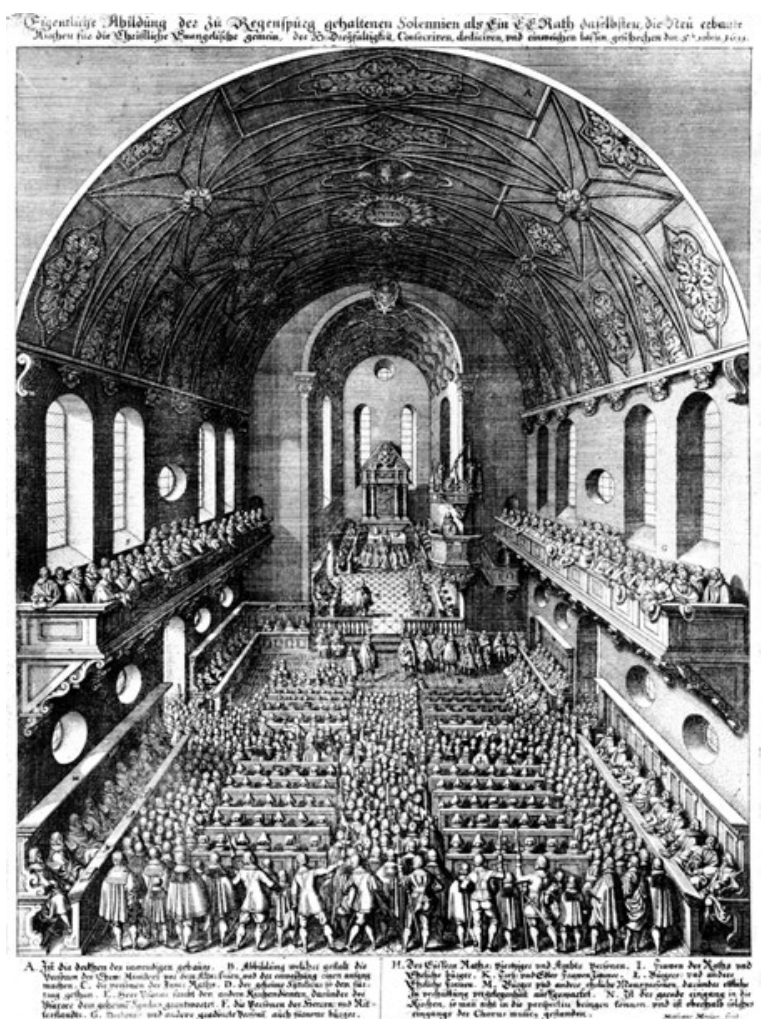

od niej za pomocą balustrady ${ }^{75}$. Podobnymi balustradami powinny być także (o ile wystarczy na to miejsca) otoczone ołtarze boczne, które należało ponadto wywyższyć na podestach ${ }^{76}$. Przyczyny stosowania takich rozwiązań wyłożył wyraziście jezuicki teolog Robert Bellarmin (1542-1621), pouczając w Disputationibus de controversiis christianae fidei, wydanych w latach 1581-1593, że oddzielenie ołtarza od wiernych świeckich jest kontynuacją zwyczaju zaprowadzonego w starożytności w Świątyni Jerozolimskiej i tak jak w niej służy wyrażeniu należytego szacunku dla świętych obrzędów sprawowanych na ołtarzu ${ }^{77}$. Arcybiskup mediolański Fryderyk Boromeusz (1564-1631) pisał wprawdzie w rozprawie De pictura sacra, ogłoszonej drukiem w roku 1624, że granicę pomiędzy ludem a ołtarzem należy zaznaczyć w jak najbardziej powściągliwy sposób w celu przybliżenia laikom Świętych Tajemnic.
Jahann Georh Bähr,

Pierwsze nabożeństwo

w kościele luterańskim

w Ratyzbonie, miedzioryt, 1631

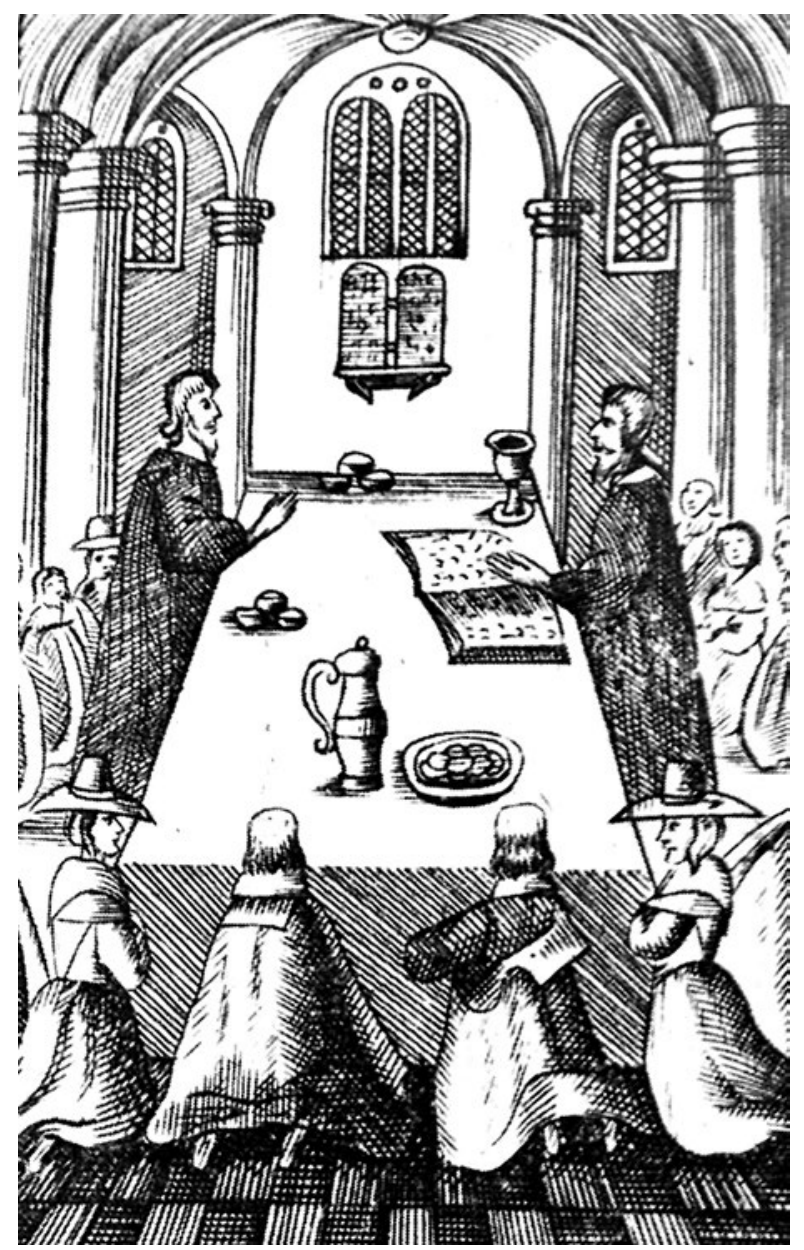

Komunia we wspólnocie purytanów, miedzioryt, około 1650 
Nie kwestionował jednak potrzeby jej wytyczenia dla zachowania właściwej „dyscypliny kultu"78. Konsekwentne utrzymywanie owej granicy uchodziło więc w Europie Środkowej za najważniejsze rozwiązanie, odróżniające w wyrazisty sposób kościoły katolickie od jednoprzestrzennych świątyń protestanckich. Odnotował to m.in. Karl Eusebius Lichtenstein (1611-1684) w Werk von der Architektur, opracowanym około roku $1675^{79}$.

Rzecz nie przedstawiała się jednak tak prosto, ponieważ kwestia kształtowania

Komunia we wspólnocie rytualistów, miedzioryt w książce Introduction to the Sacrament Lancelota Addisona, 1682

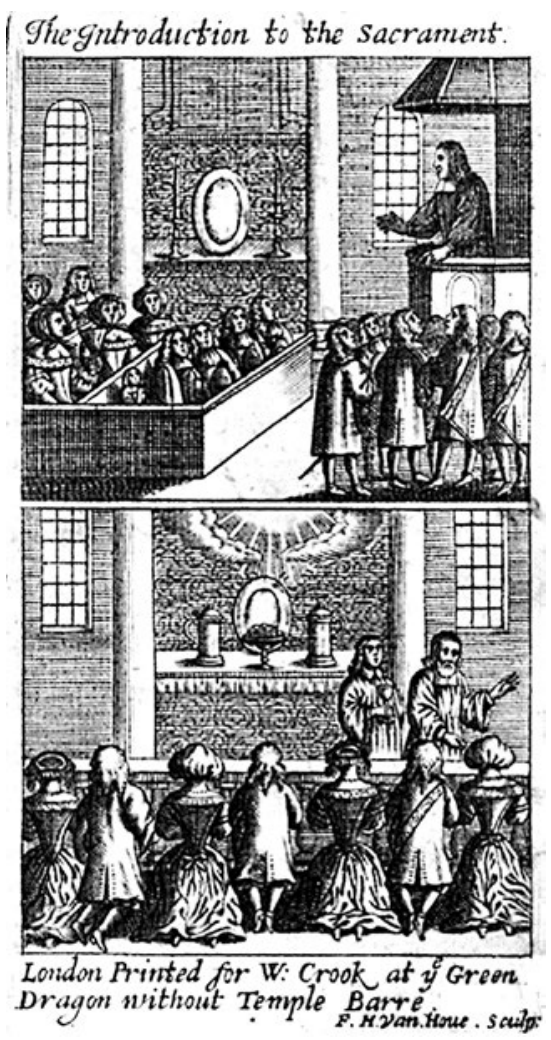
i lokalizacji ołtarza podzieliła mocno protestantów. Luter opowiedział się za zachowaniem przedreformacyjnych rozwiązań (il. 9). W Formula missae et comunionis, opracowanej dla Kościoła wirtemberskiego w roku 1523, orzekł, że „podczas Wieczerzy Pańskiej ci, którzy mają otrzymać komunię, powinni zgromadzić się w jednej grupie i w jednym miejscu. Ołtarz i prezbiterium zostały wyznaczone właśnie w tym celu"\$0. Choć niemiecki reformator nie uzasadnił bardziej szczegółowo wyboru tego rozwiązania, można domniemywać, że zaadaptował go do głoszenia swojej doktryny eucharystycznej. Nauczał bowiem, że Chrystus przybywa rzeczywiście do duszy wiernego jako zbawienny pokarm tylko wtedy, gdy ten uwierzy w Jego obecność w Najświętszym Sakramencie. Podejście wiernych $\mathrm{z}$ nawy do ołtarza w trakcie komunii było więc - według Lutra - widzialną manifestacją świadomego uczestnictwa w wielkiej tajemnicy wiary ${ }^{81}$.

Lokalizacja ołtarza w przestrzeni prezbiterium i jego ukształtowanie zostały bliżej określone w En Visitatsbok Palladiusa, który nakazał, aby sprzęt ten znajdował się „w wyodrębnionej przedniej części kościoła", bezpośrednio pod oknem w jej ścianie wschodniej ${ }^{82}$. Biskup Zelandii zalecał też, aby wymurować ołtarz w taki sposób, aby był on zarówno godnym tronem dla eucharystycznego Chrystusa, jak i wygodnym stołem dla wiernych, zobowiązanych przyjmować komunię na klęczkach, co wymagało otoczenia tego sprzętu specjalnymi klęcznikami ${ }^{83}$.

Dla kalwinistów, akcentujących przede wszystkim wspólnotowy charakter liturgii eucharystycznej, jednoczącej celebransa i wszystkich wiernych „węzłem miłości”" ${ }^{4}$, ustawienie ołtarza poza miejscem

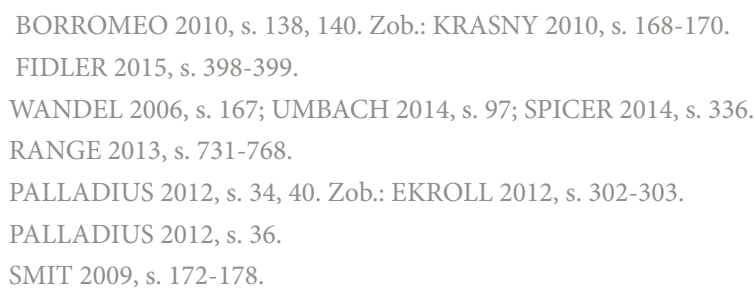


zgromadzenia ludu było rozwiązaniem nie do przyjęcia ${ }^{85}$. W nowo wznoszonych kościołach tego wyznania rezygnowano $\mathrm{z}$ wyodrębniania części ołtarzowej, gdyż - jak pisał Cornelis Danckerts (1561-1634) w Architectura moderna ofte bouwinge van onsen tyt, opublikowanej w roku 1631 - „zaprzeczało ono $\mathrm{w}$ zasadniczy sposób charakterowi publicznej liturgii”" ${ }^{\prime \prime}$. Porządki kościelne, opracowywane w Genewie, w Szwajcarii, w Szkocji i w Niderlandach, w których kalwiniści korzystali przede wszystkim ze średniowiecznych kościołów, nakazywały więc ustawiać prosty Stół Pański przed

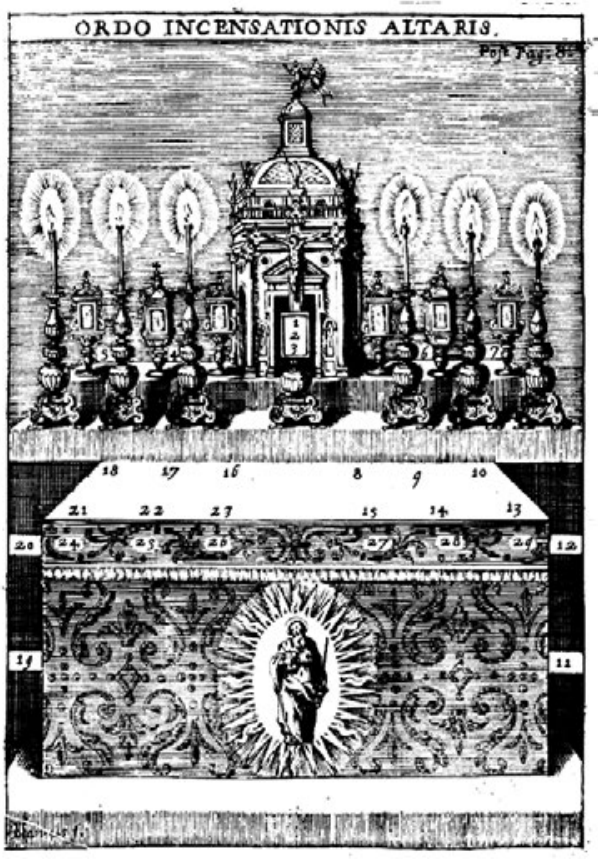
wejściem do dawnych prezbiteriów (il.

7) ${ }^{87}$. Przepisy liturgiczne formowane przez ewangelików francuskich, zmuszonych wznosić nowe świątynie, przewidywały zaś z reguły miejsce dla tego sprzętu u stóp ambony $^{88}$.

Ostre spory toczone w Kościele anglikańskim na temat istoty ołtarza, przekładały się także na zalecenia w sprawie jego kształtu i usytuowania. Skłaniający się ku protestanckiej prostocie liturgii Williams opowiadał się więc za ustawianiem Stołu Pańskiego w korpusie świątyni. Utrzymywał, że takie rozwiązanie było charakterystyczne dla czasów wczesnochrześcijańskich (o czym świadczyły - jego zdaniem - przekazy o urządzeniu wnętrza starej bazyliki św. Piotra w Rzymie), a zostało zarzucone w „Gothick buildings”, które zaczęto wznosić w okresie postępującego zepsucia Kościoła ${ }^{89}$. Pocklington, postrzegający ołtarz jak Tron Boży, propagował zaś - tak jak Palladius - przesunięcie tego sprzętu pod wschodnią ścianę prezbiterium i otoczenie go klęcznikami.Uzasadniał stosowanie tego rozwiązania zamiarem „pobudzenia w umysłach wiernych należytego szacunku i respektu poprzez rozróżnienie pomiędzy Miejscem a miejscem, Osobą a osobą, Świętym

\footnotetext{
85 BIÉLER 1961, s. 79-81; GROSSE 2008, s. 104-108.

86 DANCKERTS 1631, s. 12.

87 CALVIN 1971b, s. 239; SWIGCHEM, BROUWER, VAN OS 1984, s. 269-283; WANDEL 2006, s. 167; MANETSCH 2013, s. 275-276; SPICER 2014, s. 343.

88 THOMPSON 1995, s. 247; MENTZER Jr. 1999, s. 201; SPICER 2014, s. 348

89 WILLIAMS 1637, s. 123-136, 167-168, 198-226.
}

Porządek okadzania ottarza, miedzioryt w Missali Romano, 1731
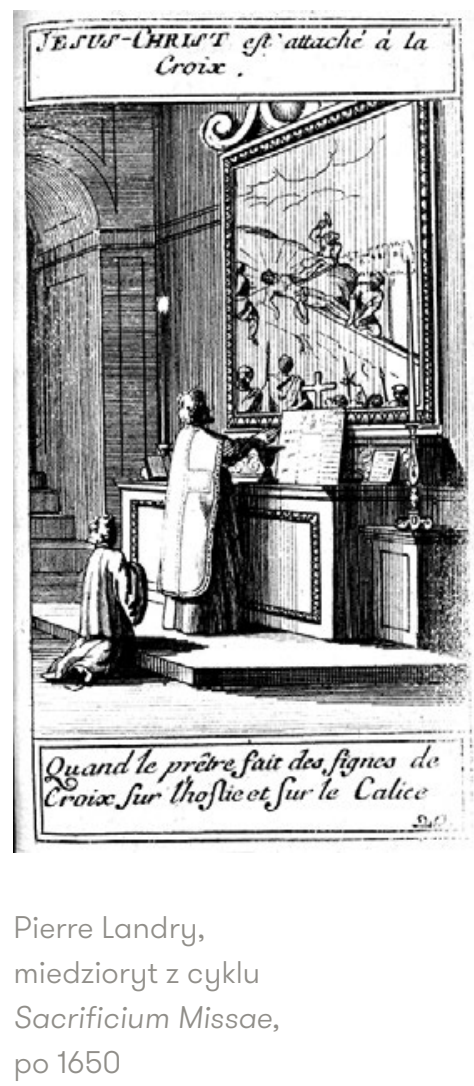

Pierre Landry, miedzioryt z cyklu Sacrificium Missae, po 1650 
a świeckim"90. Taka lokalizacja ołtarza, nakazana przez Lauda rozporządzeniem metropolitalnym w roku $1634^{91}$, została powszechnie przyjęta w Kościele angielskim od drugiej połowy XVII stulecia ${ }^{92}$.

\section{Znaczenie nastawy ołtarzowej}

Swoista redukcja form ołtarza do prostego Stołu Pańskiego i ustawienie go pośrodku kościoła, zalecone przez Butzera i przejęte przez kalwinistów oraz angielskich purytanów, wykluczało umieszczanie na owym sprzęcie jakichkolwiek retabulów. Nie sposób się zatem dziwić, że o tych elementach milczą teksty teologów owych konfesji. Większe zdumienie może jednak budzić skromna liczba wypowiedzi o nastawach ołtarzowych w piśmiennictwie katolickim.

Chociaż zdecydowana większość ołtarzy katolickich wznoszonych w średniowieczu i w epoce nowożytnej była zaopatrzona w okazałe retabula, Innocenty III i inni pisarze kościelni nie uważali owych nastaw za integralną część ołtarza $^{93}$. Definicja ołtarza zawarta i precyzyjnie zilustrowana w typicznym Mszale Rzymskim Piusa V (Michele Ghisleri, 1504-1572), wydanym w roku 1570, utożsamiała również jednoznacznie ołtarz z mensą (il. 13) ${ }^{94}$. Także Boromeusz w rozdziałach Instructionum, poświęconych ołtarzowi głównemu i ołtarzom bocznym, podał drobiazgowe wskazówki na temat kształtowania i dekoracji ich mens,

Lucas Cranach Starszy, nastawa ołtarza w Stadtkirche

w Wirttemberdze, tempera na desce, 1457. Według: WANGSGAARDJÜRGENSEN 2014

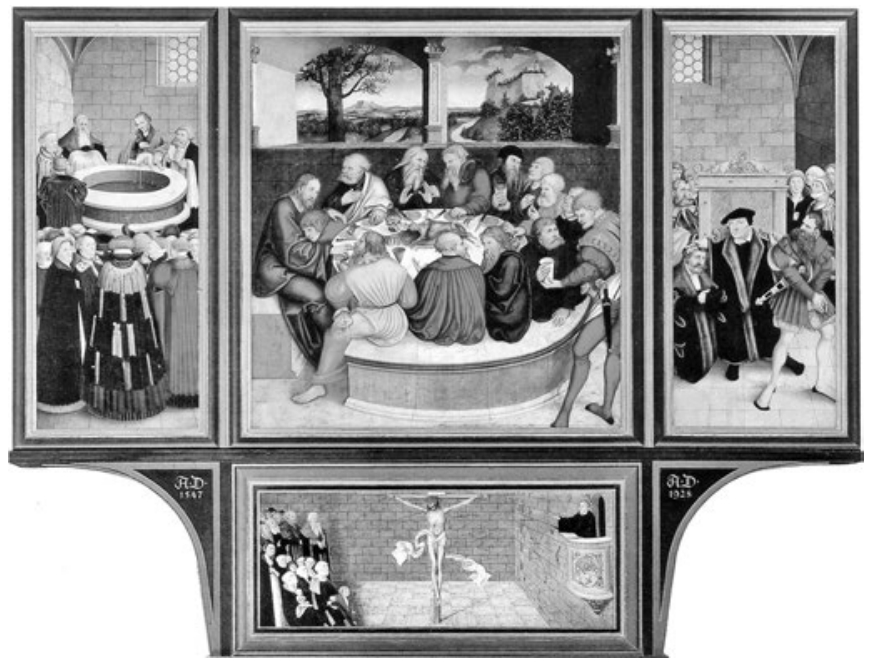

POCKLINGTON 2002, s. 102.

CRESSY 2000, s. 193.

FINCHAM 2003, s. 29-54.

WILLIAMSON 2004, s. 341-406.

Rubricae 1923, s. 20; Ritus1923 il. Ordo incensationis Altaris, s. 52. 
nie wspominając ani słowem o retabulach ${ }^{95}$. Kongregacja Świętych Obrzędów stwierdziła 5 marca 1623 roku, że ponownej konsekracji ołtarza należy dokonać tylko po uszkodzeniu lub poruszeniu jego mensy ${ }^{96}$. Można więc wyciągnąć wniosek, że nastawę uważano wyłącznie za drugorzędny dodatek do ołtarza, pozbawiony jakiegokolwiek znaczenia liturgicznego.

Z czasem zaczęto jednak akcentować, że struktura ta jest tłem dla liturgii, a więc jej program ideowy powinien stanowić stosowny i wzniosły komentarz do sprawowania Najświętszego Sakramentu97. Taką rolę przypisywał nastawom wikariusz generalny diecezji ratyzbońskiej - Jakob Müller (zm. 1597) w Ornatus ecclesiasticus. Kirchengeschmuck,

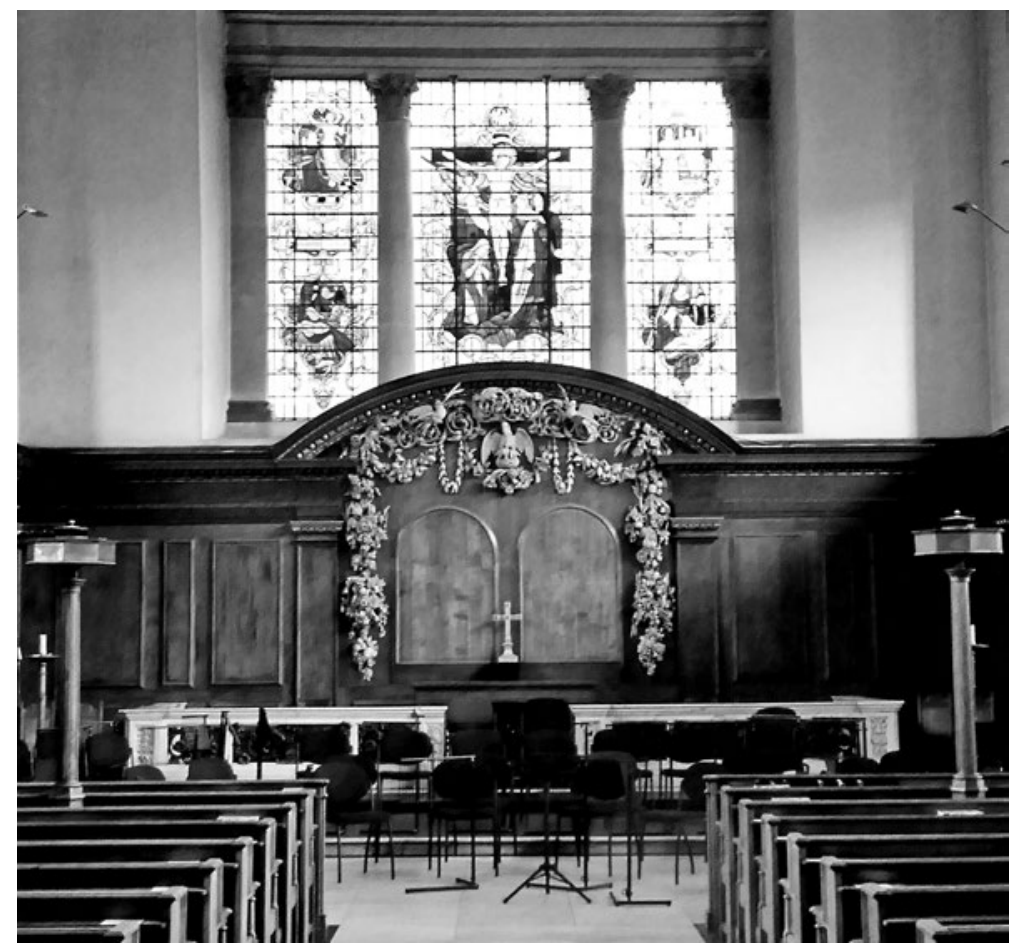
opublikowanym w roku $1591^{98} \mathrm{i}$ francuski jezuita Louis Richeôme (1544-1625) w La peinture spirituelle, ogłoszonym w roku 1611 (w którym analizował wykorzystywanie w retabulach dzieł sztuki religijnej jako „figur mistycznych”, pozwalających wiernym przeżywać głęboko ofiarniczy charakter mszy i cud transsubstancjacji $\left.{ }^{99}\right)$. Ów koncept został rozwinięty w wydawnictwach słowno-obrazowych (opracowanych m.in. przez Pierre’a

Christopher Wren, ottarz w kościele Saint James-in-the-Fields w Londynie, przed 1684, fot. Ethan Doyle White, domena publiczna Landry'ego po połowie wieku XVII (il. 14) i Aleksandra Tarasewicza w roku 1682). Manifestowały one znaczenie mszy jako pamiątki Męki Pańskiej, poprzez skonfrontowanie kolejnych rytów, sprawowanych przez kapłana na ołtarzu, z przedstawieniami etapów Pasji na obrazach w nastawie ołtarzowej ${ }^{00}$.

Zapewne nie było dziełem przypadku, że takie pomysły pojawiały się w krajach, w których katolicy stykali się bezpośrednio ze zwolennikami luterańskiej

\footnotetext{
95 BORROMAEUS 2000, s. 30-35, 40-45.

96 GIRALDI 1769, s. 419. Orzeczenie to opierało się na dekretale papieża Aleksandra III (Rolando Bandinelli, 1100-1181). Zob.: NILSSON 2014, s. 596.

97 BRAUN 1924, t. 2, s. 516-517.

98 Müller głosił, że w nastawie można umieszczać różne przedstawienia, ale za najstosowniejszy w tym miejscu uważał obraz ukrzyżowanego Chrystusa, przypominający, że msza jest pamiątką Ofiary Krzyżowej. Zob.: MÜLLER 1591, s. 83 (część łacińska), s. 84 (część niemiecka); STRECKER 1998, s. 83-84. 


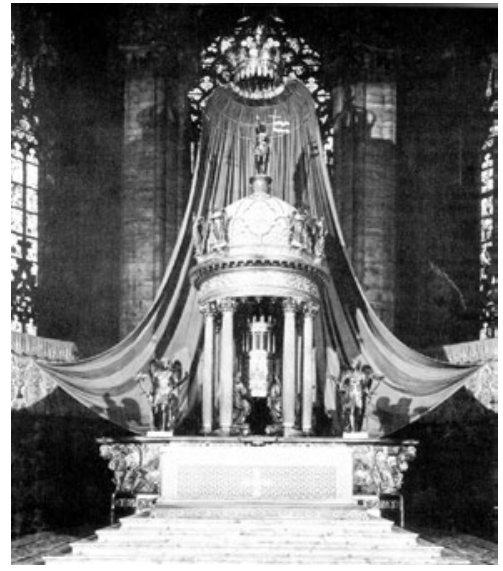

PellegrinoTibaldi, ołtarz główny w katedrze w Mediolanie, 1564. Fototeka Instytutu Historii Sztuki UJ

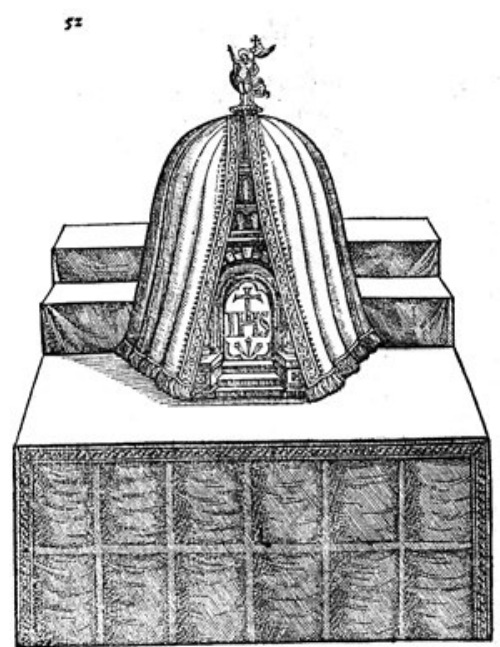

Ołtarz główny z tabernakulum, miedzioryt w książce Ornatus Ecclesiasticus. Kirchengeschmuck Jakoba Müllera, 1591 reformacji. Jej reprezentanci opisywali bowiem konsekwentnie nastawę jako integralną część ołtarza, przyjmując, że właściwe powiązanie przesłania mensy i retabulum, wzmaga wymowę ołtarza jako „świadectwa wiary”101. Luter dał dobitny wyraz takiemu przekonaniu w komentarzu do Psalmu 111, ogłoszonym w roku 1530. „Jeśli ktoś chciałby umieścić obrazy na ołtarzu - pouczał ów reformator - powinien wybrać przedstawienie Ostatniej Wieczerzy Chrystusa z dodaną do niego dwuwersową inskrypcją zapisaną złotymi literami: „Łaskawy i miłościwy Pan ustanowił pamiątkę swoich wspaniałych dzieł". Kiedy tekst ten stanie przed naszymi oczami, nasze serce zacznie kontemplować go, i nawet nasze oczy, odczytując te słowa, będą składać dziękczynienie i okazywać uwielbienie Bogu. Ponieważ ołtarz jest przeznaczony do sprawowania Sakramentu, nie sposób znaleźć lepszego obrazu do niego. Inne przedstawienia Boga i Chrystusa mogą być umieszczone w innych miejscach"102.

Ta ostatnia wskazówka nie stała się wprawdzie normą w Kościele luterańskim ${ }^{103}$, ale powszechnie przyjęto w nim koncepcję Lutra, że ikonografia obrazów i wymowa towarzyszących im inskrypcji w nastawie powinny precyzyjnie pouczać o funkcji ołtarza (il. 15) ${ }^{104}$. W Kościołach skandynawskich wydano wiele rozporządzeń, regulujących relację tych dwóch środków przekazu prawd wiary, przyznając pierwszoplanową rolę słowu. Sprawiło to, że na skrzydłach i predellach duńskich (a czasem także szwedzkich) nastaw rozpisywano spore rozprawki teologiczne, które stanowią interesujące źródło do badań nad symboliką ołtarzy w Kościele ewangelicko-augsburskim ${ }^{105}$.

Duchowni anglikańscy z kręgu Lauda, propagujący luterański model ołtarza z balustradą komunijną, przemilczeli możliwość wykorzystania nastawy obrazowej do podkreślenia symbolicznej wymowy tego sprzętu (il. 16). Arcybiskup Canterbury próbował wprawdzie wprowadzać przedstawienia figuralne do prezbiteriów kościołów. Robił to jednak w taki sposób, aby wizerunki te były wyraźnie oddzielone od ołtarza, dopuszczając je w gobelinach zawieszonych wysoko nad mensą lub w witrażach, wstawionych w okna, znajdujące się ponad nią ${ }^{106}$. Laud nie uzasadnił takiej ostrożności, ale można przyjąć, że kierował się on podobnymi racjami jak Karlstadt, który w rozprawie Abtuchung der Bylder, opublikowanej w roku 1522, pisał, iż

\footnotetext{
101 JOHANNSEN 2002, s. 88; BOTHE 2017, s. 129.

102 JOHANNSEN 2002, s. 88; WANGSGAARD-JÜRGENSEN 2014, s. 70 (tam cytowany fragment komentarza Lutra do Psalmu 111).

103 Nastawy nowożytnych luterańskich ołtarzy miały bardzo skomplikowaną i zróżnicowaną ikonografię. Zob. np.: HAEBLER 1957, s. 20-21, 31-39, 51-55; GRUNDMANN 1956, s. 151-156; HARASIMOWICZ 1979, s. 17-19; HECHT 2015, s. 55-74.

104 HARASIMOWICZ 1979, s. 21; THOFNER 2012, s. 123-125; BOTHE 2017, s. 129-132.

105 BUGGE 2001, s. 306-326; JOHANNSEN 2002, s. 88-89; KOERNER 2017, s. 349-357.

106 BAINES 1855, s. 103; GUIBBORY 1998, s. 12; PARRY 2006, s. 40-45.
} 
„nie sposób zaprzeczyć, że wielkim honorem jest znaleźć się na ołtarzu. W rzeczy samej papież uważa to za tak wielki honor, że nie pozwala pobożnym świeckim stać przy ołtarzu lub zbliżać się do niego. Zaprawdę, jest to nadzwyczajny i najwyższy honor, jeśli coś zostanie postawione na miejscu, na którym składa się Ciało Chrystusa i przy którym powinno wzywać się tylko Boga, ponieważ ołtarz został ustanowiony dla czci Boga i dla jego uwielbienia [...] Ponieważ ołtarze zostały wytworzone wyłącznie dla przyzywania Imienia Bożego, jest rzeczą dalece bardziej diabelską umieszczać na nich obrazy świętych, niż zawieszać je na ścianach"107. Anglikanie, podzielający przekonanie Pocklintona, że ołtarz jest tronem Bożym, mogli łatwo odebrać umieszczenie jakiegokolwiek wizerunku na owym sprzęcie jako akt bałwochwalczej apoteozy. Przed takim działaniem wzdragali się więc z pewnością nawet rytualiści, patrzący względnie przychylnie na bogatą oprawę kultu Bożego u katolików i luteranów.

\section{Przechowywanie Eucharystii na ołtarzu}

W nowożytnej dyspucie na temat symboliki, lokalizacji i kształtu ołtarza pisarze katoliccy nie tylko obstawali przy dawnych koncepcjach i rozwiązaniach, ale także nie uzasadniali ich w wyszukany sposób, powołując się z reguły na przedreformacyjną tradycję kościelną ${ }^{108}$. Jedynym wyłomem w takiej postawie było intensywne nawoływanie (przede wszystkim północnowłoskich) hierarchów do ustawiania na ołtarzach głównych tabernakulów. Miałyone manifestować i pobudzać - kwestionowaną przez protestantów - katolicką wiarę w transsubstancjację chleba i wina w Ciało i Krew Chrystusa, trwającą dopóki istnieją postacie ${ }^{109}$.

Stosowanie takiego rozwiązania rozpropagował biskup Werony Gian Matteo Giberti (1495-1543). W ogłoszonych w roku 1542 konstytucjach dla swojej diecezji polecił on, aby „Najświętsze Ciało było wyeksponowane wysoko, pośrodku prezbiterium, na wielkim ołtarzu, w przepięknym tabernakulum”, ponieważ dzięki takiemu usytuowaniu „dostrzegą je już na pierwszy rzut oka wszyscy” wchodzący do świątyni, co będzie wzmagać i umacniać kult Eucharystii. Odwołując się do Psalmu 122, Giberti głosił, że ,jak oczy służebnicy spoczywają na rękach pani swej [Ps 122, 2], tak oczy wszystkich, którzy stają wokół Stołu Pańskiego, powinny kierować się z bojaźnią i drżeniem ku Największemu i Najświętszemu Sakramentowi, znajdującemu się na głównym ołtarzu. Powinni oni szukać tam pocieszenia w swoich troskach i ronić łzy w pobożnym wzruszeniu, ujrzawszy ,jak słodki jest Pan” [Ps 33, 9]”"110. Pierwszy 


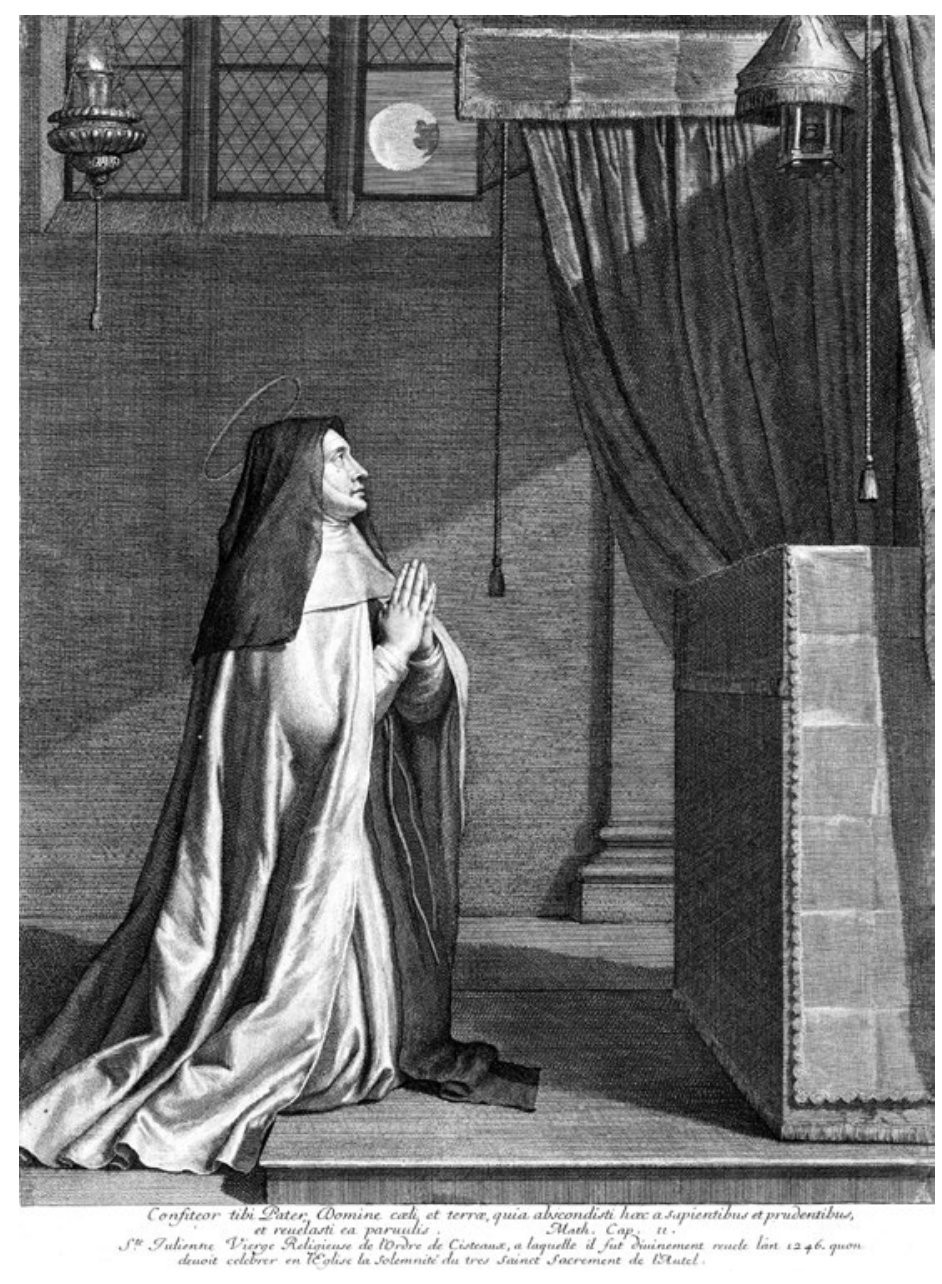

biograf Gibertiego - Pietro Francesco Zini (1526-1574) stwierdził zaś, że dzięki wystawieniu na ołtarzu głównym Eucharystia zajmuje w kościele najgodniejsze miejsce „niczym serce w piersi i umysł w duszy" ${ }^{111}$. Zalecenie biskupa werońskiego powtórzyli m.in.: legat papieski w Królestwie Angielskim Reginald Pole (15001558) w Refomationis Angliae, ogłoszonej na synodzie westminsterskim w roku $1556^{112}$, Boromeusz w dekrecie czwartego synodu mediolańskiej prowincji kościelnej, zwołanego w roku $1576^{113} \mathrm{i}$ w Instructionibus fabricae et supellectilis ecclesiasticae (il. 17) ${ }^{114}$, a także Müller w Ornato ecclasiastico. Kirchengeschmuck (il. $18)^{115}$ i biskup krakowski Bernard Maciejowski (1548-1608) w Epistola pastorali, opublikowanej w roku $1601^{116}$. Boromeusz pouczał też wielokrotnie, że ekspozycja tabernakulum na ołtarzu głównym, przypomina wiernym, że „widzenie i przebywanie w pobliżu naszego Zbawiciela [w Eucharystii] jest źródłem wielu wspaniałych darów duchowych”. Wierni są wtedy „niejako zmuszeni do tego, by coraz bardziej podziwiać Jego moc, mądrość, dobroć, a doświadczając

Jean Maron, Wizja św. Joanny z Cornillon, miedzioryt według obrazu Philippe de Champaigne'a, lata sześćdziesiąte wieku XVII w sobie ich owoców - kochać i czcić Go coraz intensywniej”"117. Dostrzegając takie korzyści duszpasterskie, papież Paweł V (Camillo Borghese, 1550-1621) nakazał w dekrecie, towarzyszącym typicznemu wydaniu Ritualis Romani w roku 1614, żeby wyeksponować tabernakula na ołtarzach głównych we wszystkich kościołach parafialnych w diecezjach rzymskich ${ }^{118}$.

Pod wpływem nauczania Pawła V taka formuła przechowywania Eucharystii przyjęła się w prawie całym Kościele katolickim. W kilku miejscach pojawiły się

\footnotetext{
111 ZINUS 1753; LANG 2009 (edycja komputerowa bez paginacji).

112 Reformatio Angliae 1562, k. 10v. Zob.: WIZEMAN 2006, s. 179, 252.

113 BORROMAEUS 1599, s. 137.

114 BORROMAEUS 2000, s. 36. Zob. też: BRAUN 1924, t. 2, s. 646-647; NAGEL 2011, s. 257.

115 MÜlLER 1591, s. 20 (część łacińska), s. 19 (część niemiecka). Zob.: BRAUN 1924, t. 2, s. 646.

116 KRASNY 2006, s. 126, 139.

117 BORROMEO 1578, k. 20r; BOROMEUSZ 2005, s. 49, 60

118 PEDROCCHI 2005, s. 124.
} 
jednak zarzuty, że owo rozwiązanie może siać zamęt $\mathrm{w}$ umysłach wiernych, którzy nie będą wiedzieli, czy adorować ciało Chrystusa przechowywane $\mathrm{w}$ tabernakulum, czy też kierować pobożność eucharystyczną ku obrzędom mszy, sprawowanym tuż przed jego drzwiczkami. Takie wątpliwości podzielał patriarcha wenecki Giovanni Trevisan (1503-1590), który w liście pasterskim z roku 1581 przyznawał wprawdzie, że „ołtarz główny, znajdujący się pośrodku kościoła, jest miejscem najgodniejszym”. Orzekł też, że w świątyniach parafialnych Republiki Weneckiej lepiej zachować lokalny zwyczaj, pozwalający „bractwom Najświętszego Sakramentu na posiadanie swoich ołtarzy [bocznych], które są przepiękne, darzone czcią i dobrze utrzymane". Hierarcha ów stwierdził też, że ołtarze te, wniesione $\mathrm{z}$ wielkim nakładem kosztów, są materialnym wyrazem autentycznej pobożności eucharystycznej, toteż nie można wykluczyć, iż owo nabożeństwo przygaśnie, kiedy Najświętszy Sakrament zostanie przeniesiony na inne miejsce ${ }^{119}$.

Obawy te podzielał arcybiskup Walencji Isidoro de Aliaga (1568-1648), który $w$ Advertencias para los edificios $y$

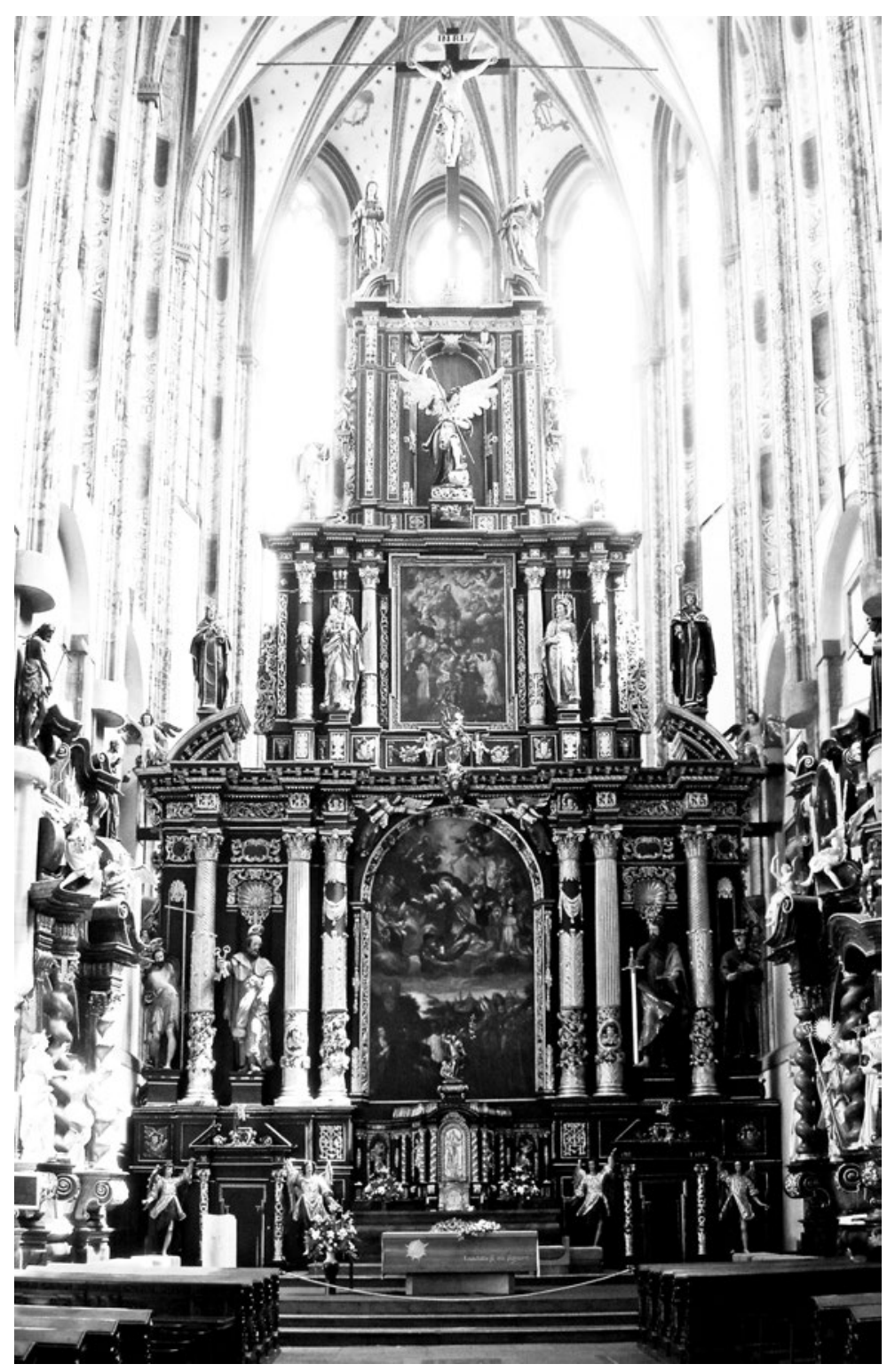
fábricas do los Templos, zatwierdzonych na synodzie metropolitalnym w roku 1631, polecił utrzymać w swojej archidiecezji „starodawny zwyczaj sytuowania tabernakulum”, nie na ołtarzu głównym, ale „na innym ołtarzu, w specjalnej kaplicy bocznej”. Aliaga uważał, że takie rozwiązanie uporządkuje kult eucharystyczny, ponieważ pozwoli licznym wiernym w tym samym czasie albo uczestniczyć godnie w uroczystej mszy, albo też przyjmować w skupieniu Ołtarz główny w kościele Panny Marie Sněžné w Pradze, 1649-1651, fot. Anton Fedorenko, domena publiczna komunię, albo adorować Chrystusa w Najświętszym Sakramencie ${ }^{120}$. 
Odmienne rozwiązanie semantycznego napięcie pomiędzy stałym przechowywaniem Ciała Chrystusa na ołtarzu i Jego uobecnieniem w tym miejscu w czasie mszy zaproponował opat klasztoru benedyktynów w Saint-Cyranne-de-Brenne Jean Duvergier de Hauranne (1581-1643) w rozprawce Raisons de la cérémonie et de la coutume ancienne de suspendre le Saint Sacrament dans les églises au dessus au Grand Autel, opublikowanej w roku 1644. Duchowny ten zalecał przechowywanie Eucharystii w puszce, osłoniętej konopeum, zawieszonej ponad ołtarzem głównym, na łańcuchu przewleczonym przez specjalny wysięgnik, osadzony w górnej części nastawy (il. 19). Podczas modlitwy eucharystycznej puszka miała wisieć wysoko nad mensą, aby nie odciągać uwagi wiernych od aktu przeistoczenia. Opuszczanie owej puszki przed komunią, powinno - według Duvergiera - pouczać wiernych, że Najświętszy Sakrament jest „chlebem żywym, który z nieba zstąpił” (J 6, 41), a jej wciągnie po komunii - przypominać słowa Chrystusa: „Gdy zostanę podwyższony nad ziemię, pociągnę wszystko do siebie" (J 12, 23) ${ }^{121}$.

Niezależnie od tego, czy katoliccy pisarze zalecali umieszczać tabernakulum na głównym, czy też na bocznych ołtarzach, koncepcja taka musiała gorszyć protestanckich teologów, kwestionujących zgodnie realną obecność Ciała i Krwi Chrystusa w postaciach eucharystycznych po zakończeniu komunii ${ }^{122}$. Oburzenie taką praktyką wyraził szczególnie dobitnie kalwiński teolog z Zurychu Rudolf Hospinian (15471626), stwierdzając, w traktacie De templis, wydanym w roku 1597 i po znacznym rozszerzeniu w roku 1603, że traktowanie zwykłego chleba jak Boga jest gorszącym bałwochwalstwem. Pisarz ów drwił również z „papistów”, że „we wszystkich swoich kościołach trzymają Eucharystię w żelaznych i zamkniętych aresztach”, a więc postępują jak oszalali kochankowie, którzy starają się zniewolić przedmiot swojego uwielbienia ${ }^{123}$. Można przypuszczać, że Hospinian nie szczędził w wypowiedzi złośliwości, dostrzegając, że rozpowszechnianie pod koniec wieku XVI zwyczaju umieszczania tabernakulów eucharystycznych na ołtarzach było przejawem przyjmowania przez Kościół katolicki zdecydowanej kontrreformacyjnej postawy. Wspólnota ta nie poprzestawała już bowiem wyłącznie na obronie swojej formuły ołtarza, ale zaczęła dopełniać ją w taki sposób, aby zamanifestować ostentacyjny sprzeciw wobec „nowinek" wprowadzonych w protestanckiej teologii eucharystycznej ${ }^{124}$.

121 DUVERGIER DE HAURANNE 1679, s. 173-187; KRASNY 2016, s. 126-131.

Taki sposób przechowywania Eucharystii nawiązywał do formuły rozpowszechnionej

we Francji w okresie średniowiecza. Zob.: BRAUN 1924, t. 2, s. 619-622. 


\section{Konkluzja}

Nowożytna dyskusja międzywyznaniowa na temat ołtarza niemal zupełnie nie objęła zagadnień szczególnie interesujących dla historyków sztuki, takich jak konkretne schematy architektoniczne, stosowne dla tych sprzętów oraz programy ikonograficzne, które powinny być zakodowane w ich nastawach. Dysputa ta doprowadziła jednak do bardzo wyrazistej polaryzacji stanowisk różnych konfesji w sprawie funkcji, jaką ołtarz powinien odgrywać w życiu liturgicznym tych wspólnot, czyniąc z owego sprzętu jeden z najważniejszych (jeśli nie najważniejszy) element ich samoidentyfikacji przez sztukę sakralną ${ }^{125}$. W znakomity sposób wyraził to francuski jezuita Jean Crasset (1618-1692) w rozprawie poświęconej afirmacji katolickiej „prawdziwej pobożności”, wydanej w roku 1677. Głosił on, iż od czasów wielkich cesarzy Konstantyna (274-337) i Justyniana (482-565) wspaniałość ołtarzy była wyrazem wiary, że w miejscach tych najświętsze Ciało Jezusa jest składane w ofierze za zbawienie ludzi. Kiedy protestanci odrzucili tę wiarę, uprościli także w zasadniczy sposób formy swoich ołtarzy. Aby zatem odrodzić i jeszcze bardziej pobudzić w ludzie pobożność eucharystyczną, należy dbać o ozdobę ołtarzy, aby swoją wspaniałością dorównywały wzorom z czasów przed reformacją ${ }^{126}$. Taka dbałość cechowała z pewnością nie tylko katolików, ale również luteranów, wierzących - wbrew temu co zdawał się im suponować Crasset - w realną obecność Chrystusa w Sakramencie Ołtarza. Nie należy zatem dziwić się, że oba te wyznania wkładały wiele wysiłku nie tylko w wystawianie w swoich świątyniach jak najefektowniejszych ołtarzy (il. 20), ale także chwaliły się wspaniałością owych sprzętów w licznych dokumentach i wydawnictwach ${ }^{127}$. Okazuje się zatem, że nowożytna dysputa religijna w sprawie ołtarza wskazała fundatorom, architektom, rzeźbiarzom i malarzom zasadnicze problemy związane z jego dostosowaniem do potrzeb liturgii, pozostawiając im zarazem wiele swobody w poszukiwaniu artystycznych rozwiązań tej kwestii. 


\section{Bibliografia:}

\section{Źródła:}

- ALBERTI 1960 - Leon Battista Alberti, Ksiag dziesięć o sztuce budowania, przeł. Irena Biegańska, Warszawa 1960.

- ALIAGA 1995 - Isidoro Aliaga, Advertencias para los edificios y fábricas do los Templos, oprac. Fernando Pingarrón, Valencia 1995.

- BELLARMINUS 1603 - Robertus Bellarminus, Disputationes de controversiischristianaefidei, t. 2, Venezia 1603.

- BOROMEUSZ 2005 - Karol Boromeusz, Rozważania o Eucharystii, przeł. Sylwester Gaworek, Warszawa 2005.

- BORROMAEUS 1599 - Carolus Borromaeus, Constitutones et decretacondita in Provinciali Synodo Mediolanensi IV, [w:] Acta Ecclesiae Mediolanesis a Carolo Cardinali Sanctae Praxedis Archiepiscopo condita, wyd. Federicus Borromaeus, Mediolani 1599, s. 111-202.

- BORROMAEUS 2000 - Carolus Borromaeus, Instructionum fabricae et supellectilis ecclesiasticae libri II, oprac. i przeł. Massimo Marinelli, Città del Vaticano 2000.

- BORROMEO 1578 - Carlo Borromeo, Libretto dei ricordi al popolo della città e diocese di Milano, Milano 1578.

- BORROMEO 2010 - Federico Borromeo, De pictura sacra, [w:] Idem, Sacred Painting. Museum, oprac. Kenenth S. Rothwell jr., Pamela M. Jones, Cambridge 2010, s. 2-142.

- BUCER 1971 - Martin Bucer, Basic Principles. Translation and Commentary of Martin Bucer's "Grund und Ursach" (1524), przeł. i oprac. Ottoman. Frederic Cypris, New York 1971.

- CALVIN 1971a - John Calvin, Antidote to the Council of Trent, [w:] idem, Selection from His Writings, oprac. John Dillinberger, New York 1971, s. 134-228.

- CALVIN 1971b - John Calvin, Draft Ecclesiastical Ordinances - 1541, [w:] idem, Selection from His Writings, oprac. John Dillinberger, New York 1971, s. 229-244.

- CALVINO 2009 - Giovanni Calvino, Istituzione della religione cristiana, oprac. Giorgio Tourn, Torino 2009.

- COMMENIUS 1648 - Iohannes Comenius, Historia persecutionum Ecclesiae Bohemicae iam inde a primoris conversationis suae ad Christianitatum, hoc est anno 894, ad annum usque 1632, Ferdinando Secundo Austriaco regnante, Lugduni Batavorum 1648.

- CRASSET 1679 - Jean Crasset, La veritable dévotion envers la sainte Vierge, Paris 1679.

- DANCKERTS 1631 - Cornelis Danckerts, Architectura moderna ofte bouwinge van onsen tyt, Amsterdam 1631.

- Dokumenty soborów 2004 - Dokumenty soborów powszechnych, t. 4: Lateran V, Trydent, Watykan I (15111870), oprac. Arkadiusz Baron, Henryk Pietras, Kraków 2004.

- DURANDUS 1859 - Gulielmus Durandus, Rationale Divinorum Officiorum, oprac. Johannes Beletus, Neapoli 1859.

- DUVERGIER DE HAURANNE 1679 - Jean Duvergier de Hauranne, Raisons de la cérémonie et de la coutume ancienne de suspendre le Saint Sacrament dans les églises au dessus au Grand Autel, [w:] idem, CEuvres chretiennes et spirituelles, t. 4, Lyon 1679, s. 173-187.

- GERHARD 2011 - Johann Gerhard, Sacred Meditations (1606), [w:] Seventeenth-Century Lutheran Meditations and Hymns, przeł. i oprac. Eric Lund, Mahwah 2011, s. 39-178.

- GIBERTUS 1733 - Iohannes Mattheus Gibertus, Constitutiones, [w:] idem, Opera nunc primum collecta, wyd. Petrus Ballerinus, Veronae 1733, s., 1-153.

- GIRALDI 1769 - Ubaldus Giraldi, Expositio Iuris Pontificii iuxta recentionem Ecclesiae disciplinam, t. 1, Romae 1769.

- HOSPINIAN 1672 - Rudolf Hospinian, De templis, hoc est de origine, progressu, usu et abusu templorum et rerum ad templa pertinentium, [w:] Idem, Opera omnia, Genevae 1672. 
- INNOCENZO III 2002 - Innocenzo III, Il sacrosanto mistero dellaltare (De sacro altaris mysterio). Romani pontificis mysteriorum evangelicae legis et Sacramenti Eucharistiae libri sex, oprac. Stefano della Torre, Massimo Marinelli, Città del Vaticano 2002.

- KARLSTADT 1998 - Andreas Karlstadt, On the Removal of Images, [w:] A Reformation Debate: Karlstadt, Emser and Eck on Sacred Images, przeł. i oprac. Bryan D. Mangrum, Giuseppe Scavizzi, Toronto 1998.

- LUTER 2011a - Marcin Luter, Mały katechizm, przeł. Andrzej Wantuła, [w:] Ksiegi wyznaniowe Kościoła luterańskiego, Bielsko-Biała 2011, s. 41-55.

- LUTER 2011b - Marcin Luter, Duży katechizm, przeł. Andrzej Wantuła, [w:] Księgi wyznaniowe Kościoła luterańskiego, Bielsko-Biała 2011, s. 57-131.

- LUTER 2011c - Martin Luter, Artykuły szmalkaldzkie z 1537 roku, przeł. Wiktor Niemczyk, [w:] Ksiegi wyznaniowe Kościoła luterańskiego, Bielsko-Biała 2011, s. 335-358.

- LUTERO 1995 - Martino Lutero, Giudizio nella necessità di abolire di messa privata, [w:] idem, Messa, sacrificio, sacerdozio (1520-1521-1534), przeł. i oprac. Silvana Nitti, Torino 1995 (= Martino Lutero, Opere scelte, t. 7), s. 147-281.

- LUTERO 1999 - Martino Lutero, Contro i profeti celesti sulle immagini e sul Sacramento, przeł. i oprac. Alberto Gallas, Torino 1999 (= Martino Lutero, Opere scelte, t. 8).

- LUTHER 1819 - Martin Luther, A Commentary on the Psalms, Called Psalms on Degrees, wyd. W. Simpkin, R. Marshall, London 1819.

- LUTHER 2011 - Martin Luther, Sermon of the Dedication of Castle Church, Torgau (1544), [w:] Nathan Montover, Luther's Revolution. The Political Dimensions of Martin Luther's Universal Priesthood, Cambridge 2011, s. 62-64.

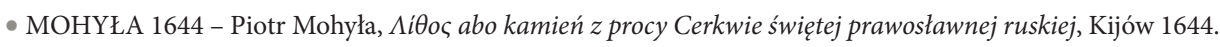

- MÜLLER 1591 - Jakob Müller, Ornatus eccleasiasticus. Kirchengeschmuck, München 1591.

- PALLADIUS 2012 - Peder Palladius, En Visitatsbog, oprac. Martin Schwarz Lausten, Frederiskberg 2012.

- PASCAL 1962 - Blaise Pascal, Prowincjałki, przeł. Tadeusz Żeleński-Boy, oprac. Leszek Kołakowski, Warszawa 1962.

- POCKLINGTON 2002 - John Pockligton, Altare christianum, Canterbury 2002.

- Reformatio Angliae 1562- Reformatio Angliae ex decretis Reginaldi Policardinalis Sedis Apostolicaelegati, Romae 1562.

- RICHEÔME 1611 - Louis Richeôme, La peinture spirituelle ou L'art d'admirer aimer et louer Dieu en toutes ses ceuures, et tirer de toutes profit salutere, Bordeaux 1611.

- RIDLEY 1841 - Nicholas Ridley, Reasons Why the Lord's Board Should Rather Be After the Form of a Table Then of an Altar, [w:] idem, The Works, wyd. Henry. Christmass, Cambridge 1841, s. 321-324.

- Ritus 1923- Ritus servandus in celebratione Missae,[w:] Missale Romanum ex decreto Sacrosancti Concilii Tridentinirestitutum, Pii V Pontificis Maximiiussueditum, Ratisbinae 1923, s. 29-36.

- Rubricae 1923 - Rubricae generales Missalis, [w:] Missale Romanum ex decreto Sacrosancti Concilii Tridentini restitutum, Pii V Pontificis Maximi iussu editum, Ratisbinae 1923, s. 16-20.

- TOMASZ Z AKWINU 1974 - Tomasz z Akwinu, Suma teologiczna, t. 28: Eucharystia, przeł. Stanisław Piotrowicz, Londyn 1974 (reedycja internetowa, strony niepaginowane).

- WILLIAMS 1637 - John Williams, Holy Table. Name and Thing, More Anciently, Properly and Literally Used Under the New Testament, Then That of an Altar, Lincoln 1637.

- ZINUS 1573 - Petrus Franciscus Zinus, Boni pastoris exemplum et specimen singulare, Venetiis 1573.

\section{Opracowania:}

- ALBARIC 1992 - Michel Albaric, Les éditions imprimées du Rationale Divinorum Officiorum du Guillaume Durand de Mende, [w:] Guillaume Durand, évêque de Mende (v. 1230-1296). Canoniste, liturgiste et homme politique, red. Pierre-Marie Gy, Paris 1992, s. 183-200.

- BAINES 1855 - John Baines, The Life of William Laud, Archbishop of Canterbury and Martyr, London 1855. - BARBÈRO 1953 - Giuseppe Barbèro, La dottrina eucaristica negli scritti di papa Innocenzo III, Roma 1953.

- BIÉLER 1961 - André Biéler, Liturgie et architecture. Le temple des chrétiens, Genéve 1961. 
- BØGILD JOHANNSEN, JOHANNSEN 2012 - Brigitte Bøggild Johannsen, Hugo Johannsen, Re-forming the Confessional Space: Early Lutheran Churches in Denmark, c. 1536-1660, [w:] Lutheran Churches in Early Modern Europe, red. Andrew Spicer, Farnham 2012, s. 241-276.

- BOSSY 1981 - John Bossy, Essai sur le sociographie de la messe, 1200-1700, „Annales, Histoire, Sciences Sociales", 36, 1981, nr 1, s. 44-70.

- BOTHE 2017 - Rolf Bothe, Kirche, Kunst und Kanzel. Luther und die Folge der Reformation, Köln 2017.

- BRAUN 1924 - Joseph Braun, Der christlische Altar und seine geschichtlichen Entwicklung, t. 1-2, München 1924.

- BUGGE 2001 - Rolf Bugge, Teksttalverne i Danmark-Norge omkrig 1600, [w:] Reformation konsolidering i de nordiska länderma, red. Erlend Bronken, Oslo 2001, s. 306-326.

- CEBALLOS 2009 - Alonso Rodriguez G. de Ceballos, Edificios singulares de España en relación con el culto eucarístico: sagrarios, capillas de comunión y capillas sacramentales, [w :] Larchitecture religieuse européenne au temps des Reformes: héritage de la Renaissance et nouvelles problématiques, red. Monique Chatenet, Claude Mignot, Paris 2009,s. 231-240.

- CRESSY 2000 - David Cressy, The Battle of Altars. Turning the Table and Breaking the Rails, [w:] idem, Travesties and Transgressions in Thudor and Stuart England. Tales of Discord of and Dissension, Oxford 2000, s. $186-216$

- CRESTI 1995 - Carlo Cresti, Architettura di altari e spazio ecclesiale. Episodi a Firenza, Prato e Ferrara nelletá delle Controriforma, Firenze 1995.

- DAVIS 1999 - Thomas J. Davis, The Truth of the Divine Worlds". Luther Sermons on the Eucharist, 1521-1528, and the Structure of Eucharistic Meaning, "The Sixteenth Century Journal", 30, 1999, nr 2, s. 323-342.

- EKROLL 2012 - Øysten Ekroll, State Church and Church State. Churches and Their Interiors in PostReformation Norway, 1537-1705, [w:] Luteran Churches in Early Modern Europe, red. Andrew Spicer, Farnham 2012, s. 277-309.

- FIDLER 2015 - Petr Fidler, Architektúra seicenta. Stavitelia, architekti a stavby viedenského dvorského okruhu $v$ Rakúsku, Čechách, na Morave a na Slovensku w 17. storočí, Bratislava 2015.

- FINCHAM 2001 - Kenneth Fincham, The Restoration of Altars in 1630s, “The Historical Journal", 44, 2001, nr 4, s. 919-940.

- FINCHAM 2003 - Kenneth Fincham, "According the Ancient Custom". The Return of Altars in the Restoration Church of England, "Transactions of the Royal Historical Society", 13, 2003, s. 29-54.

- FORTESCUE, O'CONNEL, REID 2009 - Adrian Fortescue, John Berthram. O'Connel, Alcuin Reid, The Ceremonies of the Roman Rite Described, New York 2009.

- GERRISH 1988 - Brian Albert Gerrish, Descending the Body. Sign and Reality in Luther's Controversy with the Swiss, "The Journal of Religion", 68, 1988, nr 3, s. 377-395.

- GRANE 1990 - Leif Grane, Teaching the People. The Education of Clergy and the Instruction of the People in Danish Reformation Church, [w:] Die dänische Reformation vor ihrer internationalen Hintergrund, red. Leif Grane, Kai Hørby, Göttingen 1990, s. 164-189.

- GRESCHAT 2004 - Martin Greschat, Martin Bucer. Reformer and His Time, przeł. Stephen E. Buckwalter, Lousville 2004.

- GROSSE 2008 - Christian Grosse, Les rituels de la Cène. Le culte eucharistique reformé a Genève (XVIe XVIIe siècles), Genève 2008.

- GRUNDMANN 1965 - Walter Grundmann, Die Sprache des Altars. Zur Glaubensaussage im deutschen Flügel- und Schreinaltar, Berlin 1965.

- GUIBBORY 1998 - Achsah Guibbory, Ceremony and Community from Herbert to Milton. Literature, Religion and Cultural Conflict in the Seventeenth-Century England, Cambridge 1998.

- HAEBLER 1957 - Hans Carl von Haebler, Das Bild in der evangelischen Kirche, Berlin 1957.

- HALL 1993 - Basil Hall, Martin Bucer in England, [w:] Martin Bucer. Reforming Church and Community, red. David F. Wright, Cambridge 1994, s. 144-160.

- HARASIMOWICZ 1979 - Jan Harasimowicz, Typy i programy i śląskich ołtarzy wieku Reforamcji, „Roczniki Sztuki Śląskiej“, 12, 1979, s. 7-27. 
- HECHT 2015 - Christian Hecht, Bildpolitik im Weimar der Reformationszeit. Das Cranach-Triptychon in der Weimarer Stadtkirche St. Peter und Paul, [w:] Bild und Bekenntnis. Die Cranach-Werkstatt in Weimar, red. Franziska Bomski, Hellmut T. Seemann, Thorsten Valk, Göttingen 2015.

- HERTKLOTZ 2012 - Ingo Hertklotz, Opere antiquarie nell'indice dei libri proibiti: Leon Battista Alberti, Lilio Gregorio Giraldi, Thomas Dempster, [w:] idem, La Roma degli antiquari. Cultura e erudizione tra Cinquecento e Seicento, Roma 2012, s. 67-78.

- HUMPHREY 1996 - Peter Humphrey, Altarpieces and Altar Dedication in Counter-Reformation Venice end Veneto, "Renaissance Studies", 10, 1996, nr 3, s. 371-387.

- ISAJASZ 2012 - Vera Isajasz, Early Modern Lutheran Churches. Redefining of the Boundaries of the Holy and Profane, [w:] Lutheran Churches in Early Modern Europe, red. Andrew Spicer, Farnham 2012, s. 17-37.

- IZBICKI 2015 - Thomas M. Izbicki, The Eucharist in Medieval Canon Law, Cambridge 2015.

- JANOCHA 2002 - Michał Janocha, Aleksandro Tarsevičiaus 1682 metu vilniaus graviūru ciklas „Sacrificium Missae” liturginiu-alegoriniu „Vitae Christi“ ciklųkontekste, „Acta Academiae Artium Vilnensis”, 25, 2002, s. 81-105.

- JOHANNSEN 2002 - Hugo Johannsen, The Writ on the Wall. Theological and Biblical Aspects of Biblical Text-Cycles in Evangelical Palace Chapels of the Renaissance,[w:] The Arts and the Cultural Heritage of Martin Luther, red. Eyolf Øystrem, Jens Fleisher, Nils Holger Petersen, Copenhagen 2002, s. 81-97.

- KLAJA 2008 - Grzegorz Klaja, Ołtarz w świetle teologii, Kraków 2008.

- KOERNER 2017 - Joseph Leo Koerner, Die Reformation des Bildes, München 2017.

- KRASNY 2006 - Piotr Krasny, Epistola pastoralis biskupa Bernarda Maciejowskiego z roku 1601. Zapomniany dokument recepcji potrydenckich zasad ksztaltowania sztuki sakralnej w Polsce, „Modus. Prace z Historii Sztuki", 7, 2006, s. 119-148.

- KRASNY 2010 - Piotr Krasny, Visibilia signa ad pietatem excitantes. Teoria sztuki sakralnej w pismach pisarzy kościelnych epoki nowożytnej, Kraków 2010.

- KRASNY 2016 - Piotr Krasny, Figury obecności i nieobecności. Wprowadzenie do francuskiej dysputy o świętych obrazach i o roli sztuki w życiu Kościoła w epoce nowożytnej, Kraków 2016.

- KROESEN 2010 - Justin E.A. Kroesen, Seitenaltären in mittelalterlichen Kirchen. Standort - Raum - Liturgie, Regensburg 2010.

- LABROT 1999 - Gérard Labrot, Sisyphes chrétiens. La longue patience des évêques bâtisseurs du Royaume de Naples (1590-1760), Seyssel 1999.

- LANE 2013 - Calvin Lane, The Laudians and Elizabethan Church. History, Conformity and Religious Identity in Post-reformation England, London 2013.

- LANG - Uwe Michael Lang, Tamquam cor in pectore. The Eucharistic Tabernacle Before and After the Council of Trent, „The Sacred Architecture Journal”, 15, 2009, ne 1, (edycja komputerowa bez paginacji).

- LEVERING 2005 - Matthew Levering, Sacrifice and Community. Jewish Offerings and Christian Eucharist, Oxford 2005.

- LIETZMANN 1907 - Heinz Lietzmann, Die Württemberger und Leisinger Kastenordnung, Bonn 1907.

- MALINO MALONE 2004 - Carolyn Malino Malone, Façade as Spectacle. Ritual and Ideology in Wells Cathedral, Leiden 2004.

- MANETSCH 2013 - Scott M. Manetsch, Calvin's Company of Pastors. Pastoral Care and the Emerging Reformed Churches, Oxford 2013.

- MASON RINALDI 1987 - Stefania Mason Rinaldi, „Hora di nuovo vedesi...”. Immagini della devozione eucaristica a Venezia alle fine del Cinquecento, [w:] Venezia e la Roma dei Papi, Milano 1987,s. 171-197.

- MENTZER Jr 1999 - Raymond A. Mentzer Jr., The Reformed Churches of France and the Visual Arts, [w:] Seeing Beyond the Word. Visaul Arts and Calvinist Tradition, red. Paul Corby Finney, Grand Rapids 1999, s. $199-230$.

- MOREL 2011 - Anne-Françoise Morel, Church Consecration in England 1549-1715. An Unestablished Ceremony, [w:] Foundation, Dedication and Consecration in Early Modern Europe, red. Maarten Delbeke, Minou Schraven, Leiden 2011, s. 315-330. 
- MURDOCK 2004 - Graeme. Murdock, Beyond Calvin. The Intellectual, Political and Cultural World of Europe's Reformed Churches, London 2004.

- NAGEL 2011 - Alexander Nagel, The Tabernacle in the Matrix, [w :] idem, The Controversy of Renaissance Art, Chicago 2011, s. 221-260.

- NADOLSKI 2008 - Bogusław Nadolski, Misterium chrześcijańskiego ołtarza, Kraków 2008.

- NELSON BURNETT 2011a - Amy Nelson Burnett, Karlstadt and the Origins of the Eucharistic Controversy. A Study in the Circulation of Ideas, Oxford 2011.

- NELSON BURNETT 2011b - Amy Nelson Burnett, The Social History of Communion and the Reformation of the Eucharist, „Past and Present”, 211, 2011, s. 77-119.

- NEUSER 1968 - Wilhelm Heinrich Neuser, Die Abendmahlslechre Melanchtonos und ihrer geschichtlischen Entwicklung (1519-1530), Neukirch 1968.

- NICOLÁS GÓMEZ 2006 - Dora Nicolás Gómez, Literatura artística del siglo XVIII para el estudio del la arquitectura y el ornato debido del templo christiano, [w:] En torno al Barocco. Miradas múltiples, red. Concepción. de la Peña Velasco, Murcia 2006, s. 263-289.

- NILSSON 2014 - Bertil Nilsson, The Church Law of Scania on the Consecration of Church and the Appointment of Parish Priests. International Canon Law and That of Scania, [w:] Denmark and Europe in the Middle Ages, c. 1100-1525, red. Kerstin Hundahl, Lars Kjær, Niels Lund, Farnham 2014, s. 157-182.

- PAOLUCCI 2005 - Antonio Paolucci, La "Disputa del Sacramento" di Rafaello,[w:] Alla Mensa del Signore. Capolavori dellarte europea da Rafaello a Tiepolo, red. Giovanni Morello, Torino 2005, s. 33-38.

- PARRY 2006 - Graham Parry, The Art of the Anglican Counter-Reformation. Glory, Laud and Honour, Woodbridge 2006.

- PASIERB 1968 - Janusz Pasierb, Oltarz chrześcijański. Historia i symbolika, „StudiaTheologicaVarsaviensia”, $15,1968, \mathrm{nr} 2$, s. $17-28$.

- PEDROCCHI 2005 - Annamaria Pedrocchi, Giovanni Lorenzo Bernini e Santi Ghetti: laltare maggiore in Sant'Agostino a Roma. Nuovi documenti e precisioni, "Bolletino dell'Arte", 134-135, 2005, s. 115-126.

- POLLMER-SCHMIDT, SCHMIDT 2011 - Almut Pollmer-Schmidt, Bernward Schmidt, Ritual and Its Negation. "Dedicatio Ecclesiae" and the Reformed First Sermon, [w:] Foundation, Dedication and Consecration in Early Modern Europe, red. Maarten Delbeke, Minou Schraven, Leiden 2011, s. 315-334.

- RANGE 2013 - Matthias Range, Wandelabendmahl. Protestant "Walking Communion" and Its Expression in Lutheran Material Culture, "Journal of the Ecclesiastical History", 64, 2013, nr 4, s. 731-768.

- REINBURG 1992 - Virginia Reinburg, Liturgy and the Laity in Late Medieval and Reformation France, "Sixteenth Century Journal", 23, 1992, nr 3, s. 526-547.

- RILEY 2008 - Donayon L. Riley, Palladius Peder, [w:] The Westminster Dictionary of Church History, t.1: The Early, Medieval and Reformation Eras, red. Robert Benedetto, James O. Duke, Louisville 2008, s. 487.

- SAMUEL-SCHEYDER 1993 - Monique Samuel-Scheyder, Johannes Cochlaeus, humaniste et adversaire de Luther, Nancy 1993.

- SCAVIZZI 1982 - Giuseppe Scavizzi, Arte e architettura sacra. Cronache e documenti sulla controversia tra riformati e cattolici (1500-1550), Roma 1982.

- SCAVIZZI 1992 - Giuseppe Scavizzi, The Controversy on Images from Calvin to Baronius, Bern 1992.

- SCHEPFERD 2016 - Victor A. Shepferd, Interpreting Martin Luther. An Introduction to His Life and Thought, Toronto 2016.

- SCHILLING 2017 - Heinz Schilling, Marcin Luter. Buntownik w czasach przełomu, przeł. Jerzy Kałążny, Małgorzata Kałążna, Poznań 2017.

- SCHMIDT 2003 - Victor M. Schmidt, Changing Attitudes to Sculpture from the Early Christian Period to the Counter-Reformation, [w:] Antiquity Reneved. Late Classical and Early Modern Themes, red. Zweder von Martels, Victor M. Schmidt, Leipzig 2003, s. 211-231.

- SCHOFIELD 2004 - Richard. Schofield, Architettura, dottrina e magnificenza nellarchittetura ecclesiastica delletè di Carlo e Federico Borromeo, [w:] Francesco Ripishti, Richard Schofield, Architettura e Controriforma. I dibatti per la facciata del Duomo di Milano 1582-1682, Milano 2004, s. 125-249. 
- SCHIEDER 1997 - Martin Schieder, Jenseits der Aufklärung. Die religiöse Malerei im ausgehenden Ancien régime, Berlin 1997.

- SCHWARZ LAUSTEN 2012 - Martin Schwarz Lusten, Indledning, [w:] Peder Palladius, En Visitatsbog, oprac. Martin Schwarz Lausten, Frederiskberg 2012, s. 9-24.

- SMIT 2009 - Dirkie Smit, Caritatis vinculum. The Sacrament as Bond of Charity, [w:] idem, Essays on Being Reformed. Collected Essays 3, Stellenbosch 2009, s. 172-178.

- SPICER 2014 - Andrew Spicer, Sites of the Eucharist, [w:] A Companion to the Eucharist in the Reformation, red. Lee Palmer Wandel, Leiden 2014, s. 323-363.

- ŠRONĚK 2013 - Michal Šroněk, De sacris imaginibus. Patroni, malǐri a obrazy předbělohorské Prahy, Praha 2013.

- STAECKER 2007 - Jörn Staecker, Die Reformation in Gotland - Innovation und Tradition im Kirchenraum, [w:] Archäologie der Reformation. Studien zur Auswirkungen und Konfessionswechsels auf die materielle Kultur, red. Carola Jäggi, JörnStaecker, Berlin 2007, s. 47-83.

- STEWARD 2015 - Pamela A.V. Stewart, Ritual Viewing of the Chapel of Corpus Christi. Bernardo Luinis Passion Cycle at San Giorgio a Palazzo, Milan, [w:] The Sacralisation of Space and Behaviour in the Early Modern World. Studies and Sources, red. Jennifer Mara DeSilva, Farnham 2015, s. 104-137.

- STRECKER 1889 - Freya Strecker, Augsburger Altäre zwischen Reformation (1537) und 1635. Bildkritik, Repräsentationen und Konfesionalisierung, Münster 1998.

- SWIGCHEM, BROUWER, VAN OS 1984 - C.A. van Swigchem, T. Brouwer, W. van Os, Een huis voor het Woord. Het protestantse kerk interieur in Nederland tot 1900, Den Haag 1984.

- THOFNER 2012 - Margit Thofner, Framing the Sacred. Lutheran Church Furnishings in the Holy Roman Empire, [w:] Lutheran Chursches in Early Modern Europe, red. Andrew Spicer, Aldershot 2012, s. 97-131.

- THOMPSON 1995 - Davis Thompson, Protestant Temples in France c. 1566-1623. A Pilot Study, [w:] Léglise dans l'architecture de la Renaissance, red. Jean Guillaume, Paris 1995, s. 245-256.

- THOMPSON 2005 - Nicholas Thompson, Sacrifice and Patristic Tradition in the Theology of Martin Bucer, 1534-1546,Leiden 2005.

- ULLMANN 1999 - Ernst Ullmann, Karlstadts Schrift "Von Abthung der Bylder". Ihre Entstechung und ihre Folgen, [w:] Crises de l'image religieuse. Krisen religiöser Kunst, red. Olivier Christin, Dario Gamboni, Paris 1999, s. 308-309.

- UMBACH 2014 - Helmut Umbach, Heilig - in Christus. Studien zur Raum-aspekten der Christologie im Neuen Testament, zur Kirchenraum-Pädagogik und zum protestantischen Kirchenbau heute, Göttingen 2014.

- VLČEK 2010 - Pavel Vlček, Renesančni kostely, [w:] Umění české reformace (1380-1620), red. K. Horničkova, M. Šroněk, Praha 2010, s. 245-262.

- VOGEL 2004 - Cyrille Vogel, The Development of the Private Mass, przel. William C. Storey, Niels Krogh Rasmussen, [w:] Primary Reading on the Eucharist, red. Thomas J. Fisch, Collegeville 2004, s. 27-36.

- WALTER 2017 - Peter Walter, Der Ketzer Luther. Robert Bellarmin und die Kontroversliteratur, [w:] Martin Luther: Monument, Ketzer, Mensch. Lutherbilder, Lutherprojektionen und ein ökumenischer Luther, red. Andres Holzem, Volker Leppin, Claus Arnold, Norbert Haag, Freiburg im Breisgau 2017.

- WANDEL 2006 - Lee Palmer Wandel, The Eucharist in the Reformation. Incarnation and Liturgy, Cambridge 2006.

- WANGSGAARD-JÜRGENSEN 2014 - Martin Wangsgaard-Jürgensen, Image, Time and Ritual. The Motif of the Last Supper in Lutheran Churches, [w:] Images and Objects in Rituals and Practices in Medieval and Early Modern and Central Europe, red. Krista Kodres, Anu Mänd, Cambridge 2014, s. 68-88.

- WHITE 2003 - James F. White, Protestant Worship and Church Architecture. Theological and Historical Consideration, Eugene 2003.

- WILLIAMSON 2004 - Beth Williamson, Altarpieces, Liturgy and Devotion, „Speculum”, 79, 2004, nr 2, s. 341-406.

- WIZEMAN 2006 - William Wizeman, The Theology and Spirituality of Mary Tudor's Church, Aldershot 2006. - YATES 2000 - Nigel Yates, Faith and Worship. The Liturgical Arrangement of Anglican Church, Oxford 2000.

- YATES 2004 - Nigel Yates, Liturgical Space. Christian Worship and Church Building in Western Europe 15002000, Farnham 2004. 


\section{Altare contra altare. A Dispute on the Shape of the Altar and its Decorations in the Early Modern Period}

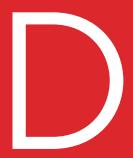

ivisions of Western Christianity, initiated in the early $16^{\text {th }}$ century and deepened in the following 200 years, led, among other things, to the embroilment between various Christian denominations regarding the issue of the symbolism of the altar, its functions, shape and location within a church. For Catholics, the altar has primarily remained the place to celebrate the Holy Sacrament, aimed at reiterating the crucifixion of Jesus and, in consequence, offering God's mercy for those participating in the liturgy and for the whole Church. Martin Luther (1483-1546) rejected this concept of the Eucharist, claiming that - according to the Bible - it was not a sacrifice, but a commemoration of the Lord's Supper. Under his influence, Martin Bucer (1491-1551), John Calvin (1509-1564) and numerous other reformers recommended substituting mediaeval stone altars with wooden tables, which, as they believed, should accordingly be called Lord's Tables. The most heated disputes on the issues of the symbolism and the shape of altars were held in the Church of England (Anglicanism). The faction known as the Puritans demanded that reformed solutions be implemented, while another group, described as 'Ritualists' opted for the preservation of the Catholic tradition. In the mid- $17^{\text {th }}$ century, the former option - justifiably grounded in the treatise by John Williams (1582-1650) - yielded to the latter, which was propagated by John Pocklington (died 1642) and inWilliam Laud's preaching (1573-1645). The dissimilar perception of the symbolism of the altar, which divided Catholics and Protestants, translated into their attitudes towards the act of its consecration. Catholics believed that it had to be 'predisposed' to perform the Lord's Supper there, since this act - due to its sacramental nature -is significantly more momentous than the 'papists' superstitious ceremony'.

Medieval theologists preached that the altar symbolises Christ, and the temple building represents the Church that gathers around Him. This symbolism, however, was obliterated in the Roman Church, where in the $6^{\text {th }}$ century numerous side altars began to be erected. This practice was also maintained after the Council 
of Trent (1545-1563), even if Charles Borromeo (1538-1584) instructed that the central altar, where the most solemn celebrations for crowds of worshippers were held, ought to be noticeably more sumptuous when compared to side altars, which were primarily used for the purpose of private masses. At the same time, Lutherans, who emphasised the community-based nature of the Lord's Supper, opted for the preservation of a single altar in a church - a postulate avidly advocated by Peder Palladius(1503-1560) in the 1540's. A similar rule was propagated by writers from other reformative communities. Nevertheless, there was a substantial clash of opinions regarding the location of the altar and the Lord's Table among Protestants. Lutherans and Anglican Ritualists believed, just like Catholics, that the worship of the Elements of the Eucharist required part of the altar to be separated, by placing it at the eastern wall of the church, and most advantageously in an isolated section of the presbytery. Calvinists and Anglican Puritans claimed that the concept of the Eucharist as vinculum caritatis, which they had applied, implied that the Lord's Table ought to be placed in the nave, in the middle of the worshipping community.

The opinion shared by the majority of writers from various religious backgrounds was that nothing else should be placed on the altar since during the Eucharist it houses its Holy Elements. Catholics did not consider reredoses to be an integral part of altars, and therefore, when describing the places for performing the Eucharist, they often chose not to mention them at all, just like Borromeo. As late as at the end of the $16^{\text {th }}$ century, the necessity of an appropriate selection of themesfor the paintings within reredoses began to be emphasised, in order for these art works to be a suitable 'commentary' to the mass liturgy. This necessity was also recognised by Lutherans, who claimed that the altar was, among other things, 'a testimony of faith', and thus, it was of crucial importance to determine an appropriate iconographic programme for its reredos, with a particular focus on the Last Supper. A weighty innovation, introduced by Catholics, was placing the tabernacle on the high altar, as advised, for instance, by Gian Matteo Giberti (1495-1543), Borromeo and Jakob Müller (died 1591). Other Catholic writers, however, believed that this solution triggered a semantic tension between the worship of the Eucharistic Christ, stored in the tabernacle, and the Christ who appears on the altar stone when the Mass is being said. Thus, Jean Duvergier de Hauranne (1581-1643) suggested returning to the medieval practice of suspending a pyx on an extension arm over the altar and lowering it onto the altar stone during Holy Communion.

Although the dispute on the altar in the Early Modern Period proved to benefactors, architects, sculptors and painters what the fundamental problems were related to its adjustment to the needs of the liturgy, it also left them a substantial amount of freedom in their search for artistic solutions to cope with these issues. 